\title{
Analysis and Evaluation of the Spatial Structure of Cittaslow Towns on the Example of Selected Regions in Central Italy and North-Eastern Poland
}

\author{
Marek Zagroba (D), Katarzyna Pawlewicz (D) and Adam Senetra *(D) \\ Department of Socio-Economic Geography, Faculty of Geoengineering, University of Warmia and Mazury \\ in Olsztyn, Prawocheńskiego 15, 10-720 Olsztyn, Poland; mazag@uwm.edu.pl (M.Z.); \\ katarzyna.pawlewicz@uwm.edu.pl (K.P.) \\ * Correspondence: adam.senetra@uwm.edu.pl; Tel.: +48-89-5234948
}

Citation: Zagroba, M.;

Pawlewicz, K.; Senetra, A. Analysis

and Evaluation of the Spatial

Structure of Cittaslow Towns on the

Example of Selected Regions in

Central Italy and North-Eastern

Poland. Land 2021, 10, 780. https://

doi.org/10.3390/land10080780

Academic Editors: Luca Salvati, Iwona Cieślak and Andrzej Biłozor

Received: 23 June 2021

Accepted: 22 July 2021

Published: 25 July 2021

Publisher's Note: MDPI stays neutral with regard to jurisdictional claims in published maps and institutional affiliations.

Copyright: (c) 2021 by the authors. Licensee MDPI, Basel, Switzerland. This article is an open access article distributed under the terms and conditions of the Creative Commons Attribution (CC BY) license (https:// creativecommons.org/licenses/by/ $4.0 /)$.

\begin{abstract}
Cittaslow International promotes harmonious development of small towns based on sustainable relationships between economic growth, protection of local traditions, cultural heritage and the environment, and an improvement in the quality of local life. The aim of this study was to analyze and evaluate the differences and similarities in the spatial structure of Cittaslow towns in the Italian regions of Tuscany and Umbria and the Polish region of Warmia and Mazury. The study examined historical towns which are situated in different parts of Europe and have evolved in different cultural and natural environments. The presented research attempts to determine whether the spatial structure of historical towns established in different European regions promotes the dissemination of the Cittaslow philosophy and the adoption of sustainable development principles. The urban design, architectural features and the composition of urban and architectural factors which are largely responsible for perceptions of multi-dimensional space were evaluated. These goals were achieved with the use of a self-designed research method which supported a subjective evaluation of spatial structure defined by historical urban planning and architectural solutions. The study demonstrated that Medieval urban layouts can be successfully incorporated into the modern urban fabric to promote sustainable development and slow living.
\end{abstract}

Keywords: Slow City; small towns; spatial structure; sustainable development; old market square; historical urban layout

\section{Introduction}

The objective of the Cittaslow International network of small towns is to promote harmonious development and slow living. This philosophy offers an alternative to globalization and the fast pace of life in large cities [1-3]. Cittaslow towns implement sustainable development policies by creating a healthy balance between economic growth, protection of local traditions, cultural heritage and the environment, and improving the quality of local life [4-6]. The members of the Cittaslow network promote local and specific values and products, and they initiate active measures to protect the natural environment and the historical urban fabric. These policies build a sense of solidarity among local community members who feel responsible for their place of residence, including its past and future $[7,8]$. The unique spatial structure of historical towns plays an important role in building harmonious relationships and adapting these towns to contemporary needs and aspirations $[9,10]$.

Small towns are human settlements that occupy a relatively limited area and organize their living space in a similar manner regardless of their location. The scale of urban development, small population, absence of industry and low levels of technical infrastructure relative to large cities contribute to sustainable development and reluctance towards modern trends that rely heavily on globalization and a fast pace of life. 
Considerable research has been dedicated to the development and future outlook of urban expansion. Zambon et al. [11] performed a quantitative analysis of urban plans to predict future urban growth patterns. The authors relied on an extensive database of social and economic indicators to examine the consequences of urban expansion in the Spanish region of Catalonia which was divided into local zones for the needs of the study. They found that urbanization had contributed little to the sustainable development of towns in recent decades. The authors concluded that future urban development in Catalonia will not follow a polycentric model, but will fuel the growth of small and medium-sized towns. The historical center of Santiago de Chile was modernized based its architectural and urban heritage. The elements of the city's original urban fabric were recreated and used to propose a new urban development concept. This approach was adopted to bridge the gap between modern requirements and the city's colonial and republican past [12]. In Senigallia, Italy, the open-design approach was implemented to regenerate the town's historical urban heritage through participatory design [13]. The town's historical district was redesigned with the use of Multicriteria Decision Analysis (MCDA). Historical districts pose a challenge for urban designers who have to reconcile conservation with modern welfare and safety standards. The MCDA approach was validated experimentally in Biella, Italy [14].

The aim of this study was to analyze the differences and similarities in the spatial structure of small towns belonging to the Cittaslow network. The evaluated towns are located in the Italian regions of Tuscany and Umbria and the Region of Warmia and Mazury in north-eastern Poland. Based on the aim of the study, the authors made an attempt to answer the following research questions:

1. Does the spatial structure of towns which are situated in different parts of Europe and have evolved under different historical, cultural and environmental conditions promote the achievement of Cittaslow goals in equal measure?

2. Which components of historical spatial structures (that developed under different functional conditions) foster the implementation of sustainable development policies and the slow living philosophy?

\section{Cittaslow International}

Current trends in urban and economic development favor measures that strengthen the growth potential of mainly large urban agglomerations. Rapid globalization has contributed to a faster pace of life. The citizens of highly developed countries show a growing appreciation for the slower approach to everyday life in smaller settlement units $[15,16]$. In small and medium-sized towns, most businesses operate only on the local market. These towns often collaborate and join various organizations to expand their economic potential. One of such organizations is the Cittaslow Movement, an international network of cities that was founded in 1999 to endorse the Slow City concept. Towns can apply for Cittaslow membership if their population does not exceed 50,000, and if they support and implement the organization's goals [17]. Candidates are evaluated in seven areas: energy and environmental policy, infrastructure policies, quality of urban life policies, agricultural, tourism and artisan policies, policies for hospitality, awareness and training, social cohesion and partnerships, based on 72 detailed criteria. Towns that meet at least $51 \%$ of these requirements are eligible for membership. They are re-evaluated (re-certified) based on the same criteria after five years [18].

The overreaching goal of the Cittaslow movement is to improve the quality of life, promote economic growth, protect the natural environment and cultural heritage, promote regional products, crafts, traditions and customs [19]. The movement advocates a slower pace of life as an alternative to the hustle and bustle of large cities and metropolises. The organization does not oppose technological progress, and its members are local economic hubs that place a high value on preserving their unique character [8]. Cittaslow members promote their towns as places with a high quality of life in the proximity of nature, highquality products and strong local communities [20]. 
The goals of the Cittaslow movement coincide with the principles of sustainable development, with the main emphasis on increasing local incomes, improving local safety, fostering a friendly social environment, improving the quality of the natural environment, enhancing spatial order and the functionality of urban spatial structures [21]. Sustainable cities are characterized by a cohesive relationship between the urban and the natural environment. Social and environmental movements play an important role, and they focus on preserving the city's unique character, restoring historical architecture, promoting local products and cuisine. In cities that are popular tourist destinations, considerable emphasis is placed on the promotion of local hospitality traditions [16,22]. Globalization increases the risk of cultural uniformity by destroying local values. The Cittaslow concept stimulates local growth as the core element of sustainable development. Member towns strive to preserve their identity and protect local values, both in the Cittaslow network and in the global context [7]. Sustainable development encompasses the environmental, social and economic aspects of urban growth. Community participation plays an important role in decision-making, and participatory processes further the sustainable development of all Cittaslow members at the local level. Cittaslow towns initiate a variety of events and projects with the involvement of the local authorities and residents, which is why the Cittaslow network is also regarded as a social movement and a local governance model [23].

The spatial layout and the potential of small historical towns are well aligned with the main tenets of the Cittaslow movement which are strongly rooted in sustainability [24]. Towns that boast the snail logo strive to improve the quality of local life and cultivate the culture of good living. The small size of urban structures, the cozy ambience of public spaces (squares, streets, parks) and small population encourage the preservation of local traditions and the search for harmony between a slow-paced life and sustainable development $[25,26]$. Historical towns are characterized by strong place identity, which promotes social integration and fosters a sense of attachment to one's home $[27,28]$. In towns with historical urban design and architecture, the residents are more likely to identify with and feel responsible for their place of residence than large city dwellers. These factors contribute to the search for novel urban planning solutions that are consistent with the Cittaslow philosophy of a slow life and eco-friendly development $[27,29]$. Historical structures in small towns well serve the above goals.

The philosophy and ideological assumptions of Cittaslow movement also fit in the evolution of spatial and urban solutions. Changes in various fields of life (economy, culture, etc.) have influenced the changes in its style. Moreover, they have an impact on the physical side of the anthropogenic space [30]. Globalization and computerization have contributed to the modification of social relations and homogenization of space in all dimensions [31]. The dominant role is played by the flow of information, idea, capital, goods and also people [32]. The quality of life indices for the certification and monitoring of the member cities are the premises of the local councils' actions. The modern ideas of spatial planning allow claiming that the sustainable development and the idea of Slow City are based on similar, or even often the same, assumptions. Duplicating the same norms in sustainable planning and the idea of the movement has become the norm emphasized in the modern debates on cities development. Consequently, the social awareness increase, spatial structures are harmonized, the elements of the environment are respected and the results of intensive urbanization are balanced. As a result, all of the above-mentioned elements become the widely acknowledged rule of good practices in planning and spatial management [30]. Moreover, they have the chance to be more widely implicated in other, more complex and more urbanized spatial arrangements.

The integral element of city development is a constant process of changes in which one of the leading roles is assigned to the processes of revitalization. It is a process that includes comprehensive operations in old towns, old districts neglected in terms of the economy, aesthetics, space, infrastructure, communication and functionality. In numerous points, the process converges with the idea of Slow City and sustainable planning. It leads to the prevention of social exclusion, facilitates socio-economic development and it also leads to 
the improvement of the quality of life of the local society. The revitalization process must be conducted according to the principles of sustainable development with the integration of social, spatial, economic, cultural, construction, investment and ecological aspects within the determined aim [33,34]. The quoted scientific and technical discourse fully confirms the necessity for the integration of the idea of Slow City, the sustainable development and technical actions (f.eg. revitalization) in a widely-acknowledged planning and land use of Cittaslow towns.

\section{Materials and Methods}

\subsection{Study Areas}

The study areas were small towns, which are Cittaslow members, in the Italian regions of Tuscany and Umbria, and the Polish region of Warmia and Mazury (Figure 1).

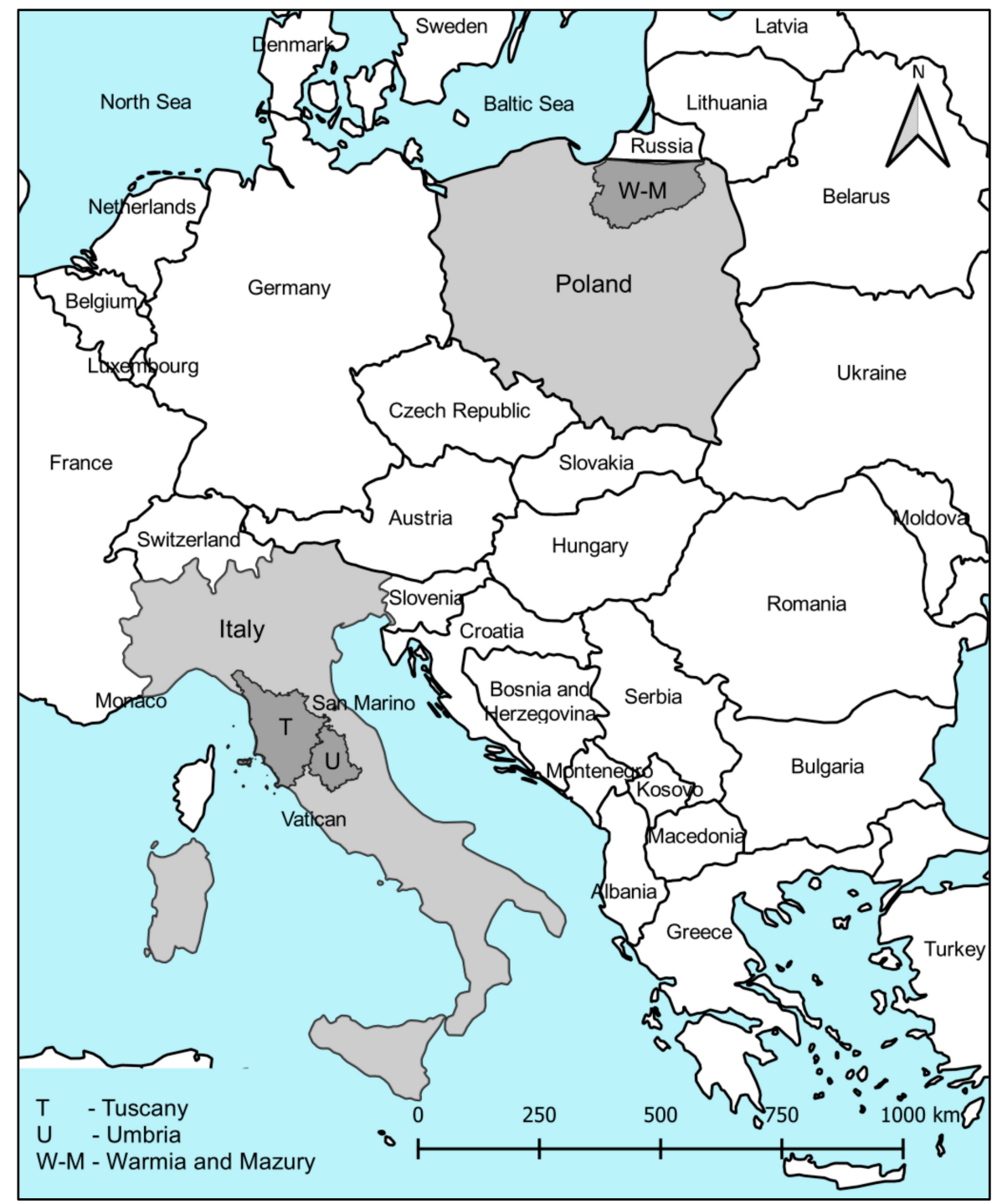

Figure 1. The analyzed regions. Source: own elaboration.

The reason for choosing Cittaslow network for the study is the fact that it is a consistent network of small towns. Moreover, it gives the possibility of conducting the research on various urban organisms. While achieving the objectives, Cittaslow solicits raising the effectiveness of economic growth, it puts emphasis on a high level of education and helps in reducing poverty; it also develops newer and newer innovative economic projects. The 
objectives fit in the ideas of sustainable development. Among strong points of Cittaslow network, one can list [35]:

- possibility of uniting nationalities that exchange experiences and create the new quality of local life;

- creating common frames for development based on "the true-life" values;

- possibility of individualized towns development based on endogenous resources;

- creating a common brand that would assure the identification on the world scale as well as on the national (local) scale;

- building partnership with inhabitants for the need of taking developmental decisions;

- building the identity of the towns' inhabitants (Cittaslow Sunday/Week);

- exchanging good practices, including study visits;

- building common socio-economic undertakings.

Cittaslow network unites mostly historical towns which drew the attention of inter alia the scientists from Massachusetts Institute of Technology City Science (USA). They stated: "We went back in time and looked at towns in which we all would like to be-a lot of them belong to the historical European towns". They think that towns that work the best are towns that had been organized before the car was invented. The towns include districts with all essential everyday life facilities. It is the so-called [36].

The value of small towns is emphasized also in The European Commission studies on the basis of which one can state that [37]:

- the towns have influence on the well-being and the living not only of their inhabitants but also the surrounding rural population,

- they make public and private service centers and they collect knowledge, create innovations and infrastructure on the local and regional scale,

- they make the base of urban regions and they give the character of regional landscapes, and determine their distinctiveness,

- their structure of growth and development in Western Europe makes the best sustainable urban system in the world,

- generic features of small and medium-sized towns, especially the human dimension, living conditions, the friendly nature of the districts and geographic rooting and historical character, make the perfectly sustainable urbanization,

- they are the indispensable element to prevent depopulation in rural areas and migration to towns; they are also necessary to reach regional sustainable development, unity and sustainable Europe.

These regions were selected for the study due to similarities in their spatial layout. The analyzed regions are highly attractive and popular tourist destinations that are widely visited by domestic tourists as well as tourists from other countries in Europe and the world. The popularity of the studied regions can be attributed to their unique environment, landscape, topographic features and cultural heritage, including historical urban fabric and world-class monuments such as castles, churches and parks [38-41]. Moreover, Tuscany is the cradle of the Cittaslow movement, whereas Warmia and Mazury is a region with the highest number of Cittaslow towns in Poland. One should mention that Polish National Cittaslow Network is the second in the terms of the number of town members in the world [35].

Small towns are characterized by similarities and differences in their topographic features, historical factors which influenced the evolution of urban structures, culture, habits, building traditions, as well as climate which shaped the local architecture. The above factors are responsible for the differences and similarities in the spatial structure of small towns, but towns that are members of the Cittaslow network pursue similar goals and strive to fulfill modern needs and aspirations. The analyzed towns differ considerably in population which ranges from 505 to nearly 28,000 in the studied Italian regions, and from 1964 to more than 23,000 in the Polish region. 


\subsubsection{Italian Towns}

Tuscan and Umbrian towns are much older than their Polish counterparts. Some Italian towns were established in Roman times, and they are regarded as the cradles of European civilization [42]. The founding dates of some towns cannot be determined accurately due to the turbulent history of the Italian peninsula. Small settlements and Roman military camps were transformed into towns that were destroyed and reconstructed on numerous occasions over the centuries. Other towns were built as part of the urbanization effort of the Roman Empire [43,44]. Topographic features and other environmental factors significantly influenced the spatial structure of Italian towns, most of which have a highly irregular street pattern [45]. However, these factors have little bearing on the preserved urban fabric which dates back to later periods in history. The present size and population of Italian towns is unrelated to topographic features [46]. The territorial reach of Italian towns continued to expand as their economies grew in successive centuries, but their original layout has been preserved to this day. The study covered 15 towns in Tuscany and 11 towns in Umbria:

1. Tuscany-Abetone Cutigliano, Anghiari, Barga, Bucine, Capalbio, Castelnuovo Berardenga, Civitella in val di Chiana, Cortona, Greve in Chianti, Marradi, Massa Marittima, Pratovecchio, San Miniato, San Vicenzo, Suvereto;

2. Umbria-Amelia, Citta della Pieve, Ficulle, Monte Castello di Vibio, Montefalco, Orvieto, Parrano, Preci, Todi, Torgiano, Trevi.

\subsubsection{Polish Towns}

The founding dates of towns in the Polish region of Warmia and Mazury are much easier to determine. Source documents citing charters that granted town rights to settlements in Warmia and Mazury have survived to this day. The relevant dates are also easier to establish because Polish towns were founded later than their Italian counterparts. Warmian and Masurian towns were granted charters because they were established on virgin territory. Their founding dates are indicated in historical documents [47].

The analyzed towns have evolved over the centuries. Their present size and population differ significantly from the original figures, but similarly to Italian towns, their historical layout can still be identified. The study analyzed 22 towns in the Polish Voivodeship of Warmia and Mazury: Barczewo, Bartoszyce, Biskupiec, Bisztynek, Braniewo, Dobre Miasto, Działdowo, Gołdap, Górowo Iławeckie, Jeziorany, Lidzbark Warmiński, Lidzbark, Lubawa, Nidzica, Nowe Miasto Lubawskie, Olsztynek, Orneta, Pasym, Reszel, Ryn, Sępopol, and Wydminy.

\subsection{Methods}

Multidimensional analyses and evaluations are required to assess the multiperspective functioning of historical towns and the ability of their spatial structures to meet the needs and aspirations of modern communities. The evaluated towns are characterized by similarities as well as differences in this respect. The objective of the applied original research methods was to verify the assumption that sustainable municipal development is closely related with spatial attributes. Some of the applied methods were based on the approaches that are widely described in the literature $[13,24,27,28,46-55]$, and they involved analyses of the current status of historical urban layout. The remaining methods were developed by the authors, and they rely on subjective evaluations of the towns' spatial structure which is defined by the historical urban fabric and architectural features. This approach is largely universal, and it can be applied in towns situated in various regions of the world. The spatial structure of the analyzed towns was assessed with the use of three criteria:

1. Multi-criteria evaluation of the spatial structure of small towns;

2. Evaluation of the influence of spatial attributes on the townscape;

3. Analysis and evaluation of the spatial structure of the studied towns. 


\subsubsection{Multi-Criteria Evaluation of the Spatial Structure of Small Towns}

The aim of this evaluation was to determine the extent to which a slower pace of life in small cities contributes to sustainable development. Due to the large number of analyzed towns (22 towns in the Polish region of Warmia and Mazury, 15 towns in Tuscany, and 11 towns in Umbria, Italy), a quantitative research method was applied to identify and systematize the key elements that determine the quality of urban spaces. The following elements were taken into consideration:

1. Founding date-iconographic sources and an analysis of the literature relating to the history of Italian towns [56,57]. Polish towns were evaluated mainly by reviewing German-language literature and iconographic sources dating back to the 19th century $[58,59]$. The aim of the analysis was to identify differences in the spatial layout of the examined towns and to determine possible correlations between a town's founding date and its urban layout (Table 1).

2. Topographic features-iconographic sources (maps, satellite images, etc.). The location of the studied towns was analyzed relative to the predominant landform types, including hills, river bends, banks of a river or another water body. Topographic features exerted a considerable influence on the layout of urban structures (Table 2).

3. Urban layout-iconographic sources (maps, satellite images, etc.). The urban planning solutions in the studied towns were analyzed in view of typical Medieval town patterns:

- towns that evolved from the existing settlements;

- towns built around Roman military camps;

- towns built in cruda radice (from a "raw root"), usually along or at the crossroads of major transportation routes.

4. Size and shape of market squares-iconographic sources (maps, satellite images, etc.). The size and shape of market squares in Medieval towns were adapted to the towns' area and economic status in the region. Market squares were assessed based on their size, organization and role in the contemporary urban structure (Table 3).

5. Town area enclosed by fortified walls, present-day area, increase in developed area (IDA) since establishment-iconographic sources (historical maps, satellite images). At the time of their foundation, the area of the studied towns was defined by fortified walls or topographic features (hill, bank of a river or another water body). The original and present area of the evaluated towns was calculated from satellite images with the use of the AutoCad software package. The territorial reach of Medieval towns was determined based on an analysis of satellite maps and the authors' knowledge of the history of urban development in Europe. The analyzed towns had undergone numerous transformations throughout history, and the calculated built-up area within fortified walls was only a rough estimate, but it was sufficient for the needs of this study. An accurate determination of the examined towns' original area would require archeological surveys which fall outside the scope of this study.

Over the centuries, continued economic growth led to the territorial expansion of the studied towns. The towns' original and present area was compared, and the attractiveness of historical urban fabric relative to modern forms of urban development was evaluated with the use of the following indicator:

$$
I D A=P A / T A F
$$

where: IDA-increase in developed area; $P A$-present area; $T A F$ - town area at the time of foundation. 
Table 1. The influence of founding date on the urban layout of the analyzed towns.

\begin{tabular}{|c|c|c|}
\hline No. & Period of Origin & Urban Layout \\
\hline 1. & $\begin{array}{l}\text { Roman era } \\
\text { (3rd century } \\
\text { BCE-5th century } \\
\text { CE) }\end{array}$ & $\begin{array}{l}\text { - towns were built around Roman military camps; } \\
\text { towns developed around the existing settlements (irregular } \\
\text { urban layout). }\end{array}$ \\
\hline 2. & $\begin{array}{l}\text { Early Medieval } \\
\text { period (8th to 10th } \\
\text { century) }\end{array}$ & $\begin{array}{l}\text { - towns were built around Roman military camps; } \\
\text { - towns developed around the existing settlements (unplanned } \\
\text { urban layout); } \\
\text { - towns were built in cruda radice (from a "raw root") with } \\
\text { irregular urban layout or a grid street pattern. }\end{array}$ \\
\hline 3. & $\begin{array}{l}\text { Medieval period } \\
\text { (11th to } 14 \text { th century) }\end{array}$ & $\begin{array}{l}\text { - towns developed around the existing settlements (irregular } \\
\text { - } \quad \text { towns layout); } \\
\text { irregular urban layout or a grid street pattern. }\end{array}$ \\
\hline
\end{tabular}

Source: own elaboration based on Tołwiński [48].

Table 2. Correlations between landform and urban planning solutions.

\begin{tabular}{|c|c|c|}
\hline No. & Topographic Feature & Urban Planning Solutions \\
\hline 1. & Hill with steep slopes & $\begin{array}{ll}\text { - } & \text { grid street plan or irregular urban layout; } \\
\text { - } & \text { dense urban network; } \\
\quad \text { dense development resulting from space constraints. }\end{array}$ \\
\hline 2. & River bend & $\begin{array}{l}\text { - grid street plan with various degrees of regularity; } \\
\text { uncontrolled urban development in the direct vicinity of } \\
\text { the river; } \\
\text { - urban expansion in a direction opposite to the river. }\end{array}$ \\
\hline 3. & $\begin{array}{l}\text { Bank of a river or another water } \\
\text { body }\end{array}$ & $\begin{array}{l}\text { - } \quad \text { grid street plan; } \\
\text { rib pattern or a regular grid patter; } \\
\text { urban expansion in a direction opposite to the river or } \\
\text { another water body. }\end{array}$ \\
\hline
\end{tabular}

Source: own elaboration based on Czubiel and Domagała [47].

Table 3. Shape and size of market squares in the studied towns.

\begin{tabular}{|c|c|c|}
\hline No. & $\begin{array}{l}\text { Shape of Market } \\
\text { Square }\end{array}$ & Size of Market Square \\
\hline 1. & a & $\begin{array}{l}\text { The shape and relative surface area of the market square (ratio of } \\
\text { market area to town area) influence perceptions of urban structures. }\end{array}$ \\
\hline 2. & $\mathbf{a}$ & $\begin{array}{l}\text { Based on their shape and size, market squares can be perceived as } \\
\text { neutral, harmonious, elongated, dynamic, aggressive or cohesive. }\end{array}$ \\
\hline 3. & $\mathbf{a}$ & The relative surface area of market squares in the analyzed towns \\
\hline 4. & $\mathbf{\Delta}$ & $\begin{array}{l}\text { was classified as: } \\
0.4-2.5 \%-\text { small: }\end{array}$ \\
\hline 5. & 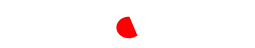 & $2.6-10.0 \%$-average: \\
\hline 6. & $\square$ & $10.1-21 \%$-large \\
\hline
\end{tabular}

Source: own elaboration based on Czubiel and Domagała [47].

\subsubsection{Evaluation of the Influence of Spatial Attributes on the Townscape}

This stage of the research involved cartographic methods as well as field surveys of Polish towns and selected Italian towns. Urban structures were evaluated by directly experiencing the distinctive atmosphere of historical towns. Direct observations were supplemented by analyses of photographs and video footage. Iconographic sources such as maps and satellite images were also used to examine the key elements of the urban structure. These research methods supported assessments of individual spatial attributes which stimulate the senses and enable spectators to experience the unique/distinctive atmosphere of a place (genius loci). The following factors were taken into consideration: 
1. Urban layout-cartographic sources, observations and field surveys. The extent to which Medieval urban forms have been preserved was evaluated to determine whether and to what degree the development of the studied towns affected their original design. According to Camillo Sitte, an urban theorist whose work exerted a considerable influence on contemporary urban planning, the designers of Medieval towns in Italy appreciated the value of irregularity and esthetics in the urban form [54]. The evolution of Italian towns was influenced by topographic and environmental features as well as their territorial expansion over the centuries. Polish towns were established based on a different set of principles. Their streets followed a strict geometric pattern that was adapted to local conditions, including topographic and environmental features. Towns are living organisms that evolve over time. For this reason, the functions of Medieval towns should be adapted to modern requirements without compromising their original urban layout that has been shaped by historical, topographic and cultural factors. Street patterns were analyzed in:

- Italian towns with a free-form urban pattern and an irregular street network, where the junction of the main roads acts as a focal point in the town center;

- Polish towns with a grid street pattern, rigid compositional axes and a clearly defined central area.

The urban forms in both Polish and Italian towns are aesthetically pleasing, but they evoke completely different perceptions of urban space (Table 4).

Table 4. The influence of urban design on perceptions of space.

\begin{tabular}{|c|c|c|}
\hline No. & Criterion & Perceptions of Space \\
\hline 1. & Free-form urban composition & $\begin{array}{l}\text { - } \quad \text { authentic historical experience; } \\
\text { - } \quad \text { enhanced/reduced esthetic experience; } \\
\text { - } \quad \text { unpredictable urban planning solutions. }\end{array}$ \\
\hline 2. & Grid street plan & $\begin{array}{l}\text { - } \quad \text { visual stimuli support the formulation of } \\
\text { comprehensive perceptions of urban space; } \\
\text { - } \quad \text { spatiotemporal series; } \\
\text { - predictable urban planning solutions. }\end{array}$ \\
\hline
\end{tabular}

Source: own elaboration based on Hall [49], Wejchert [51], Gzell [54].

2. Urban open spaces-urban open spaces such as municipal squares, pocket parks and small public parks were analyzed in Italian and Polish cities. The evaluated open spaces differed in form and design, they were user-friendly and attracted local residents as well as tourists (Table 5).

3. Architecture-local surveys of the quality of urban space. Buildings and structures are the key elements of the townscape, and they build a sense of local identity. Urban architecture is responsible for the distinctive atmosphere of a place and subjective perceptions of the built environment. The unique ambience of Medieval towns can be largely attributed to historical architecture. The form, layout, scale and detail of architectural design, the applied building materials, their texture and color directly influence the human senses. Non-material factors, such as the town's founding date and important historical events, are also powerful stimuli that generate positive perceptions of space [60]. The historical architecture of the studied towns was analyzed to determine its influence on esthetic and sensory perceptions of space. Architecture is the main element of the urban fabric which influences the quality and attractiveness of space. A town's architecture stimulates the senses and creates an esthetic experience (Table 6).

4. Conservation status of historical architecture-iconographic sources, field surveys. The conservation status of historical architecture in the studied towns was evaluated based on source documents and knowledge of the history of architecture. The results 
were used to estimate the date of construction, identify the architectural style and assess the authenticity of the analyzed buildings (Table 7).

5. Scale of urban development- - the area of the studied towns was analyzed in view of historical changes in their territorial reach relative to their original area. The territorial expansion of Medieval towns was an inevitable consequence of their economic growth. The historical architecture in the center of small towns has to be preserved against the background of modern development to maintain the esthetic composition of the urban structure. This is a necessary prerequisite for preserving the unique identity of historical towns, and it demonstrates that towns are living organisms that evolve over time (Table 8 ).

Table 5. The influence of urban open spaces on perceptions of space.

\begin{tabular}{|c|c|c|}
\hline No. & Criterion & Perceptions of Space \\
\hline 1. & Squares & $\begin{array}{l}\text { - user-friendly spaces; } \\
\text { architecture and green infrastructure contribute to social } \\
\text { integration and a sense of local identity. }\end{array}$ \\
\hline 2. & Municipal parks & $\begin{array}{l}\text { - } \quad \text { recreational areas; } \\
\text { architecture and green infrastructure contribute to a sense of } \\
\text { identity and responsibility for one's place of residence. }\end{array}$ \\
\hline
\end{tabular}

Source: own elaboration based on Wejchert [51], Montgomery [53].

Table 6. The influence of architecture on perceptions of space.

\begin{tabular}{|c|c|c|}
\hline No. & Criterion & Perceptions of Space \\
\hline 1. & $\begin{array}{l}\text { Individual buildings and } \\
\text { structures }\end{array}$ & $\begin{array}{l}\text { - } \quad \text { form, scale, building materials, facade color; } \\
\text { - } \quad \text { architectural style; } \\
\text { - } \quad \text { no estitive/negative esthetic experience; } \\
\text { no expence. }\end{array}$ \\
\hline 2. & $\begin{array}{l}\text { Frontage buildings, urban } \\
\text { block }\end{array}$ & $\begin{array}{l}\text { - } \quad \text { diverse architectural forms and styles; } \\
\text { - } \quad \text { form, division, rhythm, roof pattern, building } \\
\text { - } \quad \text { enhaterials, facade color; } \\
\text { - } \quad \text { genius loci; } \\
\text { - } \quad \text { architecture contributes to a sense of local identity. }\end{array}$ \\
\hline
\end{tabular}

Source: own elaboration based on Burgess [28], Norberg-Schulz [52], Radwan [55].

Table 7. The influence of urban components on perceptions of the townscape.

\begin{tabular}{|c|c|c|}
\hline No. & Conservation Criteria & Assessment \\
\hline 1. & Historical urban design & $\begin{array}{l}\text { - } \quad \text { analysis of cartographic sources; } \\
\text { - } \quad \text { field surveys; } \\
\text { - knowledge of the history of urban planning. }\end{array}$ \\
\hline 2. & Historical architecture & $\begin{array}{l}\text { - } \quad \text { analysis of iconographic sources; } \\
\text { - } \quad \text { field surveys; } \\
\text { - } \quad \text { knowledge of the history of architecture. }\end{array}$ \\
\hline 3. & $\begin{array}{c}\text { Identification of the market } \\
\text { square }\end{array}$ & $\begin{array}{l}\text { - } \quad \text { preservation of the original shape, structure and size; } \\
\text { conservation status of historical buildings flanking } \\
\text { the market square; } \\
\text { - quality of urban space (urban and architectural } \\
\text { design, street furniture). }\end{array}$ \\
\hline
\end{tabular}


Table 7. Cont.

\begin{tabular}{lll}
\hline No. Conservation Criteria & \multicolumn{1}{c}{ Assessment } \\
\hline D. & Dominant buildings & $\begin{array}{l}\text { conservation status of dominant buildings in the } \\
\text { historical townscape (church, town hall, tower, } \\
\text { fortified structures); } \\
\text { composition of townscape elements based on the } \\
\text { preserved dominant buildings. }\end{array}$ \\
5. & - & $\begin{array}{l}\text { distinctive atmosphere; } \\
\text { subjective emotional perceptions associated with } \\
\text { historical architecture. }\end{array}$ \\
\hline Source: own elaboration based on Norberg-Schulz [52], Zagroba and Gawryluk [24].
\end{tabular}

Source: own elaboration based on Norberg-Schulz [52], Zagroba and Gawryluk [24].

Table 8. Factors responsible for the territorial expansion of the studied towns.

\begin{tabular}{|c|c|c|}
\hline No. & Criterion & Assessment \\
\hline 1. & Historical center & $\begin{array}{l}\text { - the urban layout of the historical center is consistent with the } \\
\text { original town plan dating back to the period of establishment; } \\
\text { dense, intensive development; } \\
\text { - } \quad \text { the scale of urban development accentuates the historical } \\
\text { center against the backdrop of contemporary urban areas; } \\
\text { - historical buildings have a consistent architectural style; } \\
\text { - historical centers have a unique atmosphere (genius loci). }\end{array}$ \\
\hline 2. & $\begin{array}{c}\text { Developed areas } \\
\text { outside the historical } \\
\text { center }\end{array}$ & $\begin{array}{l}\text { - unlike historical towns, contemporary urban structures are } \\
\text { planned along regional transportation routes; } \\
\text { - } \quad \text { dispersed development; } \\
\text { the scale of urban development is largely influenced by the } \\
\text { historical center; } \\
\text { modern architecture is radically different from historical } \\
\text { - urban forms; } \\
\text { modern urban development is devoid of the unique } \\
\text { atmosphere of historical centers. }\end{array}$ \\
\hline
\end{tabular}

Source: own elaboration based on Alexander [27], Benevolo [46], Rossi et al. [13].

The factors listed in Table 8 were used to evaluate the quality of urban space in historical towns. The quality of the historical urban fabric is determined by perceptions of structural archetypes, distinctive features that contrast with contemporary urban structures outside the historical center, as well as compositional factors such as the scale of urban development and urban forms.

\subsubsection{Analysis and Evaluation of the Spatial Structure of the Studied Towns}

An intuitive (holistic) research method was applied to determine the extent to which the distinctive ambience (genius loci) of historical towns shapes the urban landscape in the evaluated regions and contributes to an improvement in the local standard of living. The influence of urban design elements, including structures, buildings, town blocks, streets and squares, on the quality of urban space was evaluated in Polish and Italian towns. Historical architecture and urban design are manifestations of a region's cultural heritage, and they evoke strong emotional responses. The analysis revealed strong links between the quality of local life and the protection of heritage sites. These relationships have evolved differently in Italian and Polish towns, which can be attributed to differences in culture, climate and history (Table 9). 
Table 9. Preservation of historical spatial components in the studied towns.

\begin{tabular}{|c|c|c|}
\hline No. & $\begin{array}{c}\text { Subjective } \\
\text { Evaluation-Genius loci }\end{array}$ & $\begin{array}{c}\text { Preservation of Historical Spatial Components of } \\
\text { Urban Space }\end{array}$ \\
\hline 1. & Preserved & $\begin{array}{l}\text { - } \quad \text { town blocks preserved in original form; } \\
\text { - } \quad \text { preserved historical architecture; } \\
\text { - distinctive atmosphere of a historical town. }\end{array}$ \\
\hline 2. & Partly preserved & $\begin{array}{l}\text { minor modifications of historical components exert a } \\
\text { negligible influence on the overall legibility of urban } \\
\text { design; } \\
\text { foreign and modern architectural forms exert a } \\
\text { minor effect on historical urban design; } \\
\text { the existing urban structure has a predominantly } \\
\text { historical character. }\end{array}$ \\
\hline 3. & Neutral & $\begin{array}{l}\text { - considerable modifications of historical components } \\
\text { significantly compromise the overall legibility of } \\
\text { urban design; } \\
\text { - a predominance of foreign architectural forms } \\
\text { significantly detracts from historical urban design; } \\
\text { the structural layout of historical towns is difficult to } \\
\text { identify. }\end{array}$ \\
\hline 4. & Not preserved & $\begin{array}{l}\text { - the legibility of the original urban design has been } \\
\text { lost; } \\
\text { architectural design does not make a reference to } \\
\text { historical forms; } \\
\text { - urban spaces do not reflect the town's history. }\end{array}$ \\
\hline
\end{tabular}

Source: own elaboration based on Rossi [50], Norberg-Schulz [52].

\section{Results}

The data collected with the use of the described research method were interpreted based on three criteria for analyzing the spatial structure of the studied towns. The results of the study are presented separately for each stage of the conducted research for greater readability.

\subsection{Multi-Criteria Evaluation of the Spatial Structure of Small Towns-Results}

Italian towns differ considerably in founding dates because they were established from Roman times to the Medieval period (Figures 2 and 3).

Most of the analyzed Polish towns were established in same century (Figure 4).

The spatial structure of Italian and Polish towns was determined by topographic features and environmental conditions. All towns were founded in areas with favorable terrain characteristics (hill with steep slopes, river bend, bank of a river or another water body) which acted as natural barriers and protected the inhabitants against enemies (Figure 5).

A centrally located market square has always occupied an important place in the spatial structure of the studied towns. The size and shape of historical market squares differ considerably in the analyzed urban structures, but most towns have rectangular market squares (Figure 6).

The size of urban structures in Medieval towns was determined by the towns' economic status and technical capabilities (Tables 10-12). The average area of Medieval towns within fortified walls was determined at 3.89 ha in Tuscany, 6.04 ha in Umbria, and 5.37 ha in Warmia and Mazury. Over the centuries, economic growth fueled the expansion of the analyzed urban structures outside defensive walls. Tables 10-12 present the developed area of Italian and Polish towns, not the area enclosed by their administrative boundaries (which includes undeveloped areas such as forests, water bodies and agricultural land). 
Only built-up areas with the accompanying green infrastructure were measured based on orthophotomaps.

The area enclosed by fortified walls was used to calculate the relative area of the market square, which was expressed as the ratio of market square area to developed urban area (Figures 7 and 8). The average relative market square area was determined at $2.15 \%$ in Tuscany, $1.91 \%$ in Umbria, and $10.92 \%$ in Warmia and Mazury.

As demonstrated by Figures 9 and 10, the studied towns continued to expand dynamically throughout history. The greatest territorial expansion was noted in the 19th and 20th centuries. The character and density of urban development also evolved, and this process was accompanied by changes in urban design and architectural style. The average increase in developed area was determined at $19.89 \%$ in Tuscan towns, $16.50 \%$ in Umbrian towns, and $25.35 \%$ in Polish towns in the Region of Warmia and Mazury.

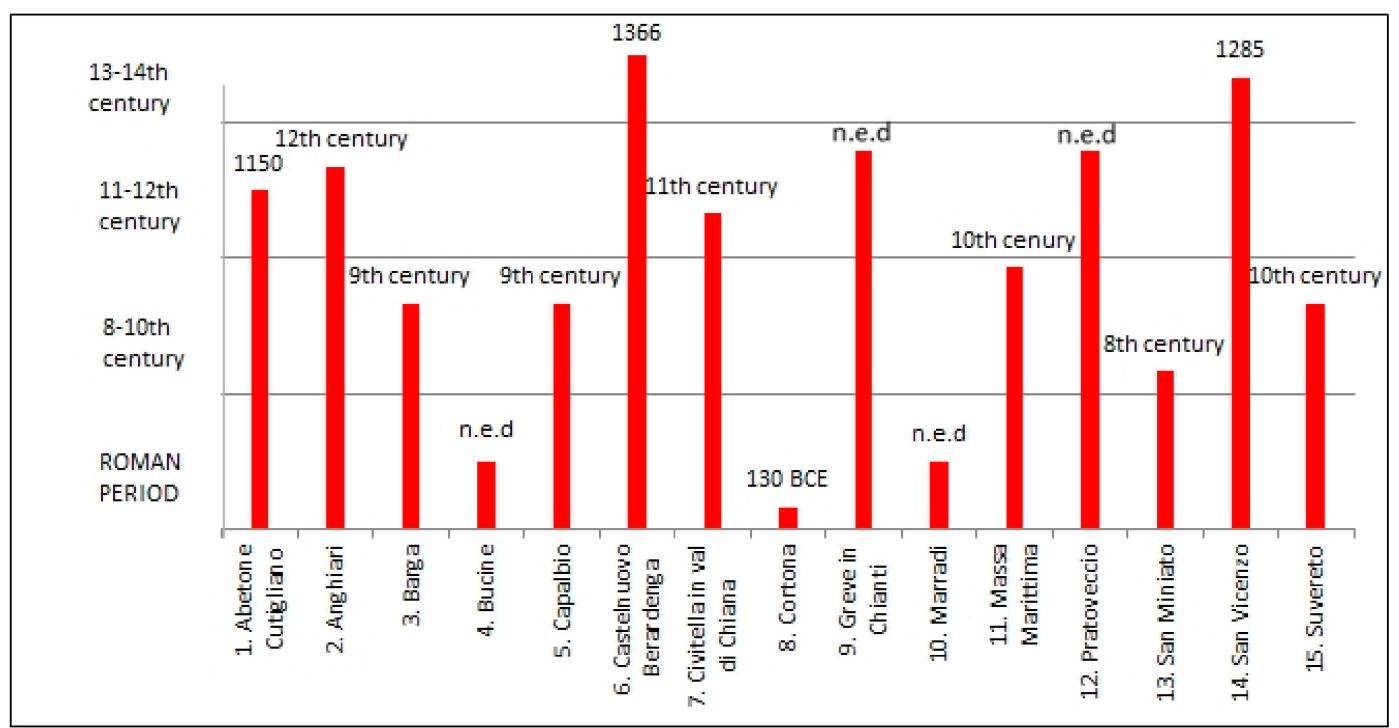

Figure 2. Founding dates of Tuscan towns. Source: own elaboration based on the data published by the Italian National Institute of Statistics [61] and Atlante Storico Iconografico Delle Città Toscane [62]. Key: n.e.d—no exact data available.

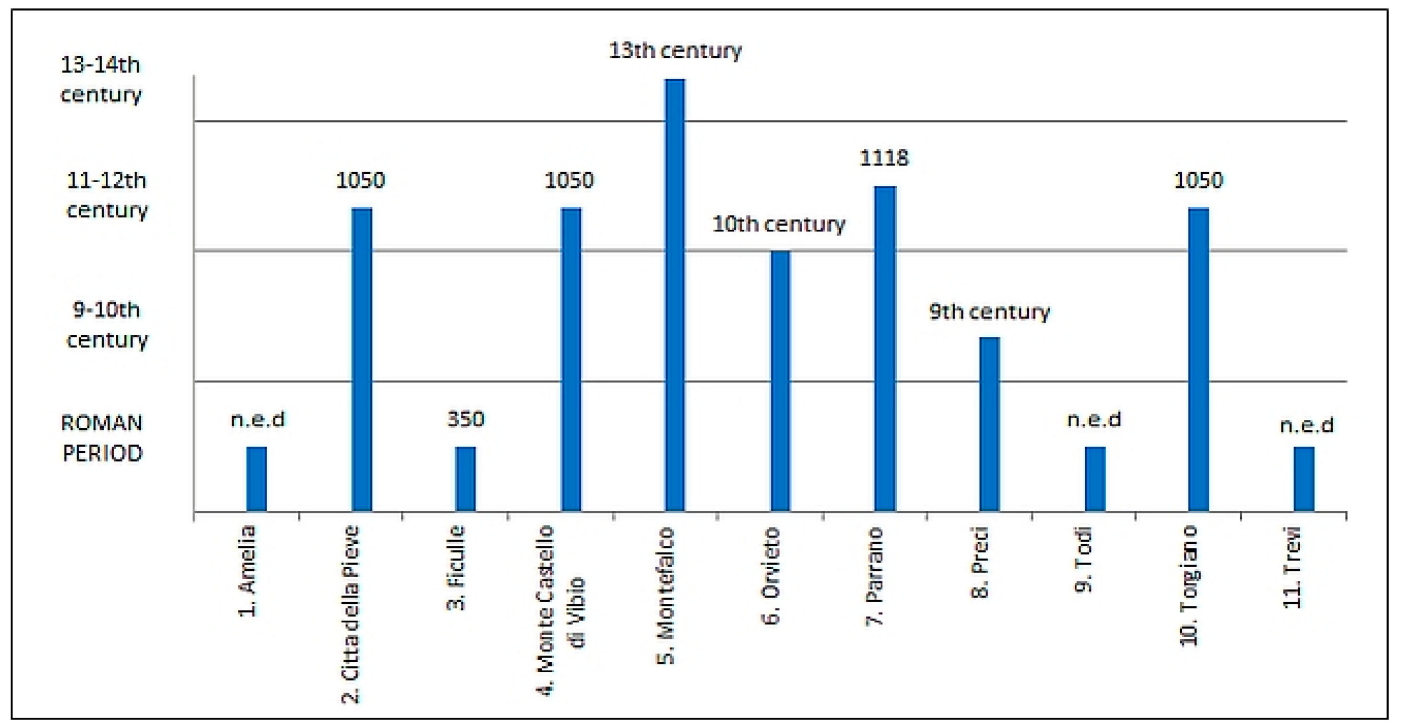

Figure 3. Founding dates of Umbrian towns. Source: own elaboration based on the data published by the Italian National Institute of Statistics [61] and Ross [63]. Key: n.e.d-no exact data available. 


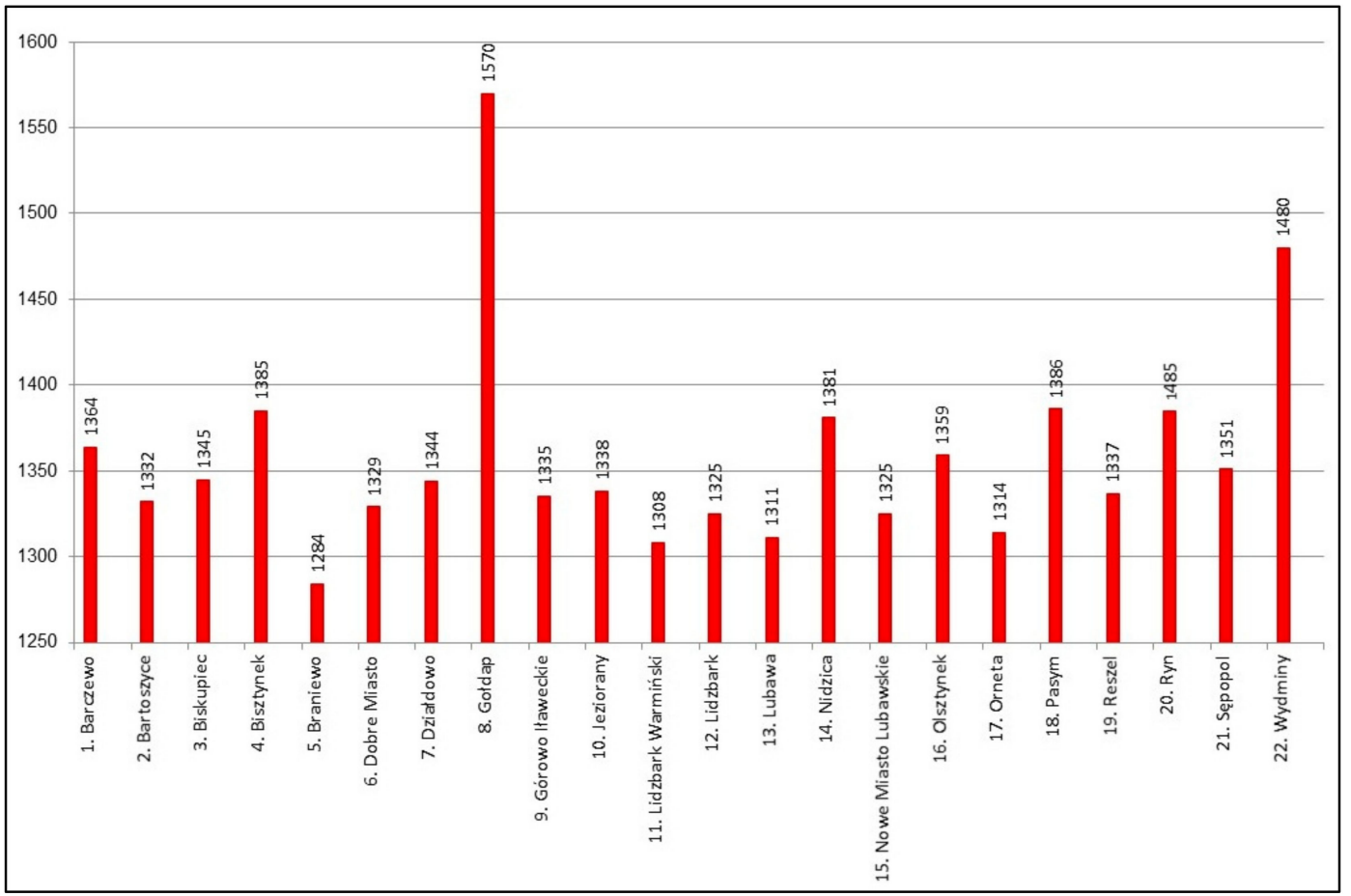

Figure 4. Founding dates of Polish towns. Source: own elaboration based on Czubiel and Domagała [47].

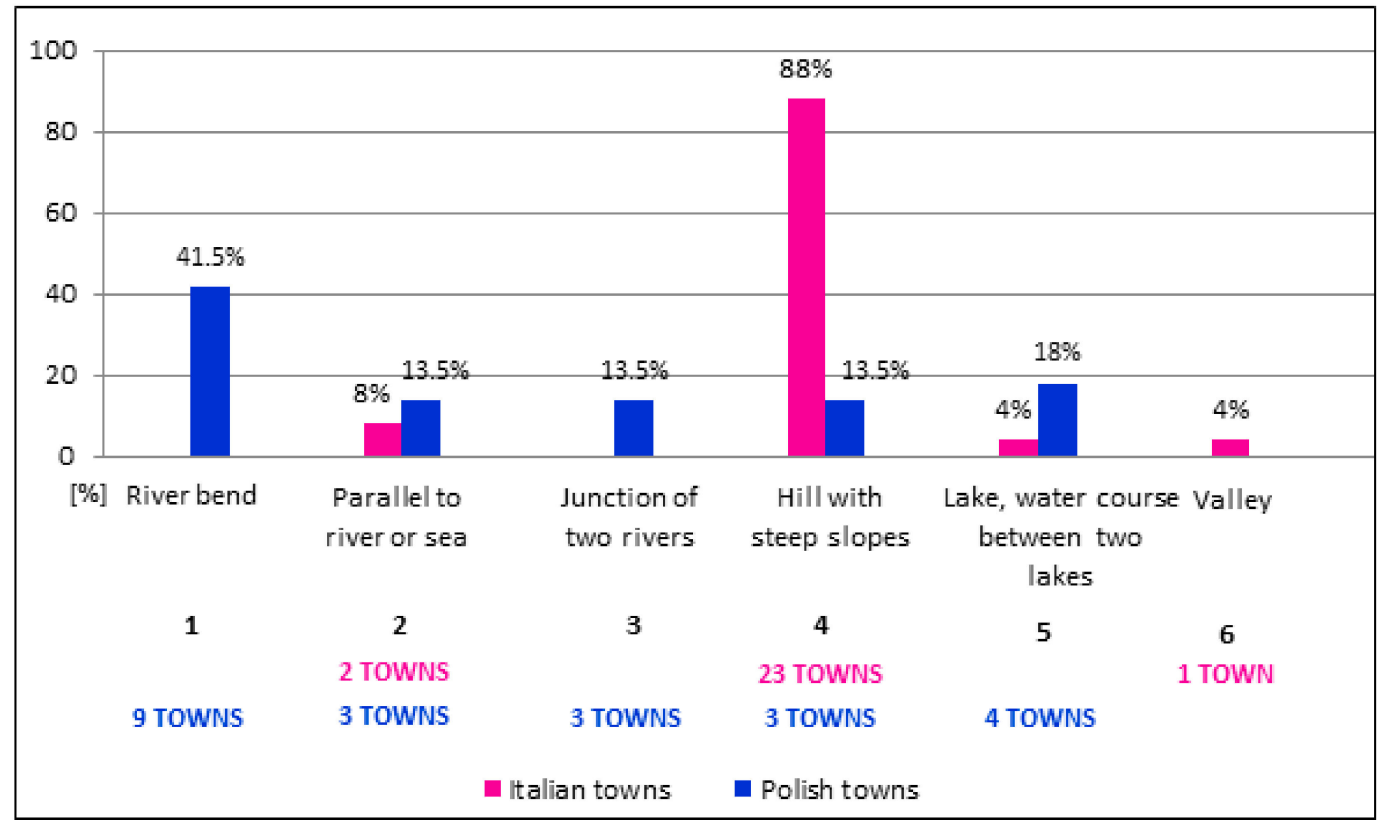

Figure 5. Topographic features in Polish and Italian towns. Source: own elaboration based on cartographic analyses. Key: 1-Polish 9 towns: Bartoszyce, Biskupiec, Braniewo, Lidzbark Warmiński, Nidzica, Nowe Miasto Lubawskie, Olsztynek, Reszel, Sepopol; 2-Italian 2 towns: Maradi (T), San Vicenzo (T); Polish 3 towns: Bisztynek, Działdowo, Gołdap; 3-Polish 3 towns: Barczewo, Dobre Miasto, Lubawa; 4-Italian 23 towns: Abetone Cutigliano (T), Anghiari (T), Barga (T), Bucine (T), Capalbio (T), Castelnuovo Berardenga (T), Civitella in val di Chiana (T), Cortona (T), Massa Marittima (T), Pratovecchio (T), San Miniato (T), Suvereto (T), Amelia (U), Citta della Pieve (U), Ficulle (U), Monte Castello di Vibio (U), Montefalco (U), Orvieto (U), Parrano (U), Preci (U), Todi (U), Torgiano (U), Trevi (U); Polish 3 towns: Jeziorany, Lidzbark, Orneta; 5-Polish 4 towns: Górowo Iławeckie, Pasym, Ryn, Wydminy; 6-Italian 1 town: Greve in Chianti (T); (T)—Tuscany, (U)—Umbria. 


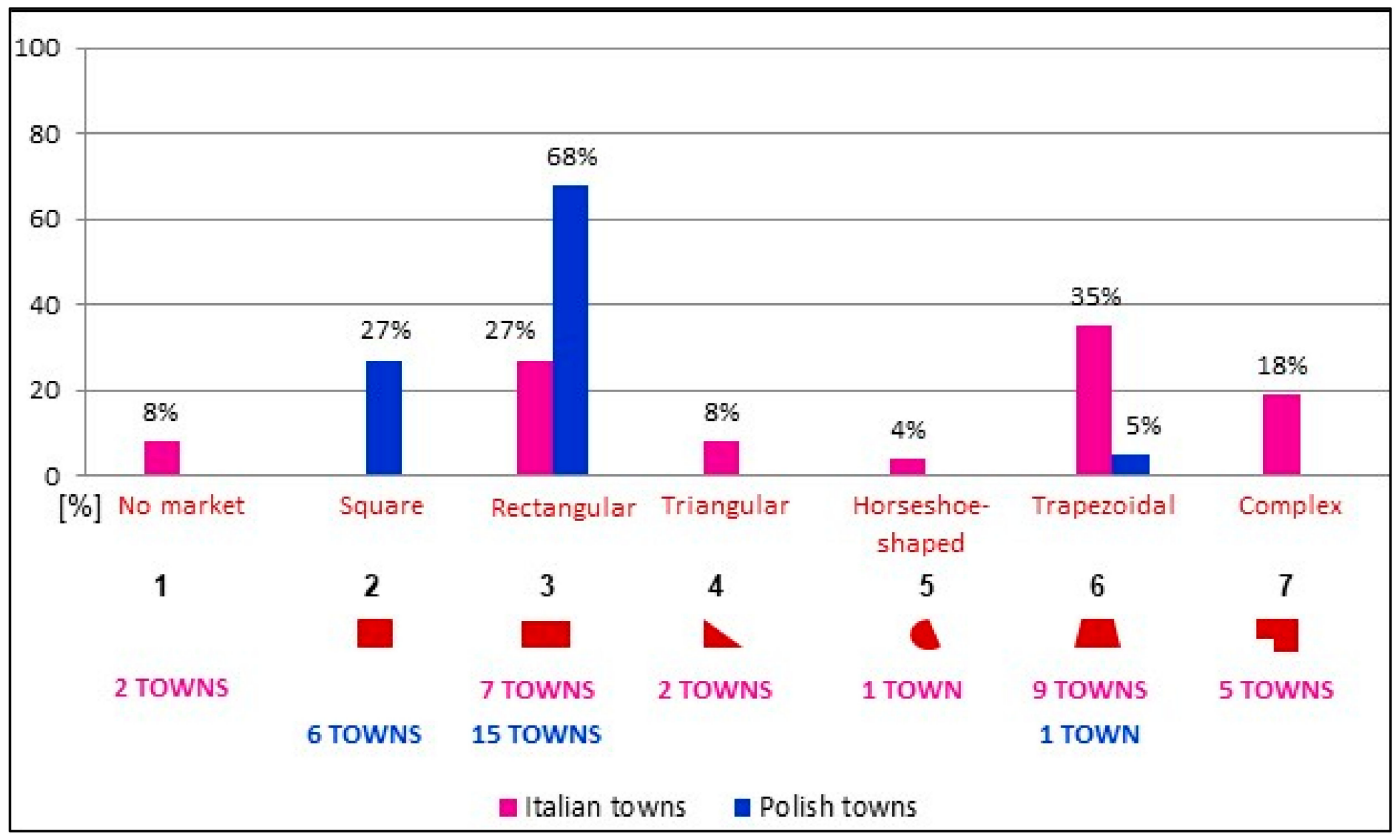

Figure 6. Shape of market squares in Italian and Polish towns. Source: own elaboration. Key: 1-Italian 2 towns: Bucine (T), San Vicenzo (T); 2-Polish 6 towns: Działdowo, Gołdap, Lidzbark Warmiński, Lubawa, Nowe Miasto Lubawskie, Reszel; 3-Italian 7 towns: Capalbio (T), Marradi (T), Suvereto (T), Monte Castello di Vibio (U), Orvieto (U), Todi (U), Torgiano (U); Polish 15 towns: Barczewo, Bartoszyce, Biskupiec, Bisztynek, Braniewo, Dobre Miasto, Górowo Iławeckie, Jeziorany, Lidzbark, Olsztynek, Orneta, Nidzica, Pasym, Ryn, Wydminy; 4-Italian 2 towns: Castelnuovo Berardenga (T), Greve in Chianti (T); 5-Italian 1 town: Montefalco (U); 6-Italian 9 towns: Barga (T), Civitella in val di Chiana (T), Cortona (T), San Miniato (T), Citta della Pieve (U), Preci (U), Ficulle (U), Parrano (U), Trevi (U); Polish 1 town: Sepopol; 7-Italian 5 towns: Abetone Cutigliano (T), Anghiari (T), Massa Marittima (T), Pratovecchio (T), Amelia (U).

Table 10. Tuscan towns-developed area.

\begin{tabular}{cccc}
\hline No. & Town & $\begin{array}{c}\text { Developed Area within } \\
\text { City Walls [ha] }\end{array}$ & $\begin{array}{c}\text { Contemporary } \\
\text { Built-Up Area [ha] }\end{array}$ \\
\hline 1. & Abetone Cutigliano & 2.2 & 26 \\
2. & Anghiari & 2.3 & 116 \\
3. & Barga & 6.5 & 140 \\
4. & Bucine & 0 & 71 \\
5. & Capalbio & 1.5 & 19 \\
6. & Castelnuovo Berardenga & 2.8 & 56 \\
7. & Civitella in val di Chiana & 2.2 & 43 \\
8. & Cortona & 13.7 & 55 \\
9. & Greve in Chianti & 5.1 & 72 \\
10. & Marradi & 3.3 & 83 \\
11. & Massa Marittima & 6.2 & 125 \\
12. & Pratovecchio & 7.0 & 75 \\
13. & San Miniato & 2.1 & 150 \\
14. & San Vicenzo & 0 & 274 \\
15. & Suvereto & 3.4 & 57 \\
\hline
\end{tabular}

Key: zero values denote cities without fortified walls; contemporary built-up area-urbanized area (developed area with the accompanying green infrastructure). Source: own elaboration based on Cittaslow Italia [64] and Google Maps [65]. 
Table 11. Umbrian towns-developed area.

\begin{tabular}{cccc}
\hline No. & Town & $\begin{array}{c}\text { Developed Area Within } \\
\text { City Walls [ha] }\end{array}$ & $\begin{array}{c}\text { Contemporary } \\
\text { Built-Up Area [ha] }\end{array}$ \\
\hline 1. & Amelia & 12.6 & 139 \\
2. & Citta della Pieve & 5.4 & 102 \\
3. & Ficulle & 2.5 & 22 \\
4. & Monte Castello di Vibio & 2.4 & 27 \\
5. & Montefalco & 3.3 & 56 \\
6. & Orvieto & 9.3 & 92 \\
7. & Parrano & 1.2 & 19 \\
8. & Preci & 1.9 & 39 \\
9. & Todi & 13.4 & 198 \\
10. & Torgiano & 9.0 & 128 \\
11. & Trevi & 5.4 & 212 \\
\hline
\end{tabular}

Key: contemporary built-up area-urbanized area (developed area with the accompanying green infrastructure) Source: own elaboration based on Cittaslow Italia [64] and Google Maps [65].

Table 12. Towns in Warmia and Mazury—developed area.

\begin{tabular}{cccc}
\hline No. & Town & $\begin{array}{c}\text { Developed Area within } \\
\text { City Walls [ha] }\end{array}$ & $\begin{array}{c}\text { Contemporary } \\
\text { Built-Up Area [ha] }\end{array}$ \\
\hline 1. & Barczewo & 6.0 & 458 \\
2. & Bartoszyce & 9.0 & 1179 \\
3. & Biskupiec & 6.0 & 500 \\
4. & Bisztynek & 6.0 & 216 \\
5. & Braniewo & 9.0 & 466 \\
6. & Dobre Miasto & 6.0 & 486 \\
7. & Działdowo & 8.4 & 1147 \\
8. & Gołdap & 0 & 38 \\
9. & Górowo Iławeckie & 5.6 & 332 \\
10. & Jeziorany & 4.5 & 341 \\
11. & Lidzbark Warmiński & 6.0 & 1435 \\
12. & Lidzbark & 4.8 & 568 \\
13. & Lubawa & 4.8 & 1684 \\
14. & Nidzica & 6.0 & 686 \\
15. & Nowe Miasto Lubawskie & 8.4 & 1137 \\
16. & Olsztynek & 4.8 & 769 \\
17. & Orneta & 8.0 & 963 \\
18. & Pasym & 4.5 & 1518 \\
19. & Reszel & 6.0 & 382 \\
20. & Ryn & 0 & 414 \\
21. & Sępopol & 4.5 & 463 \\
22. & Wydminy & 0 & 83 \\
\hline
\end{tabular}

Key: zero values denote cities without fortified walls; contemporary built-up area-urbanized area (developed area with the accompanying green infrastructure). Source: own elaboration based on Cittaslow Polska [66] and Google Maps [65]. 


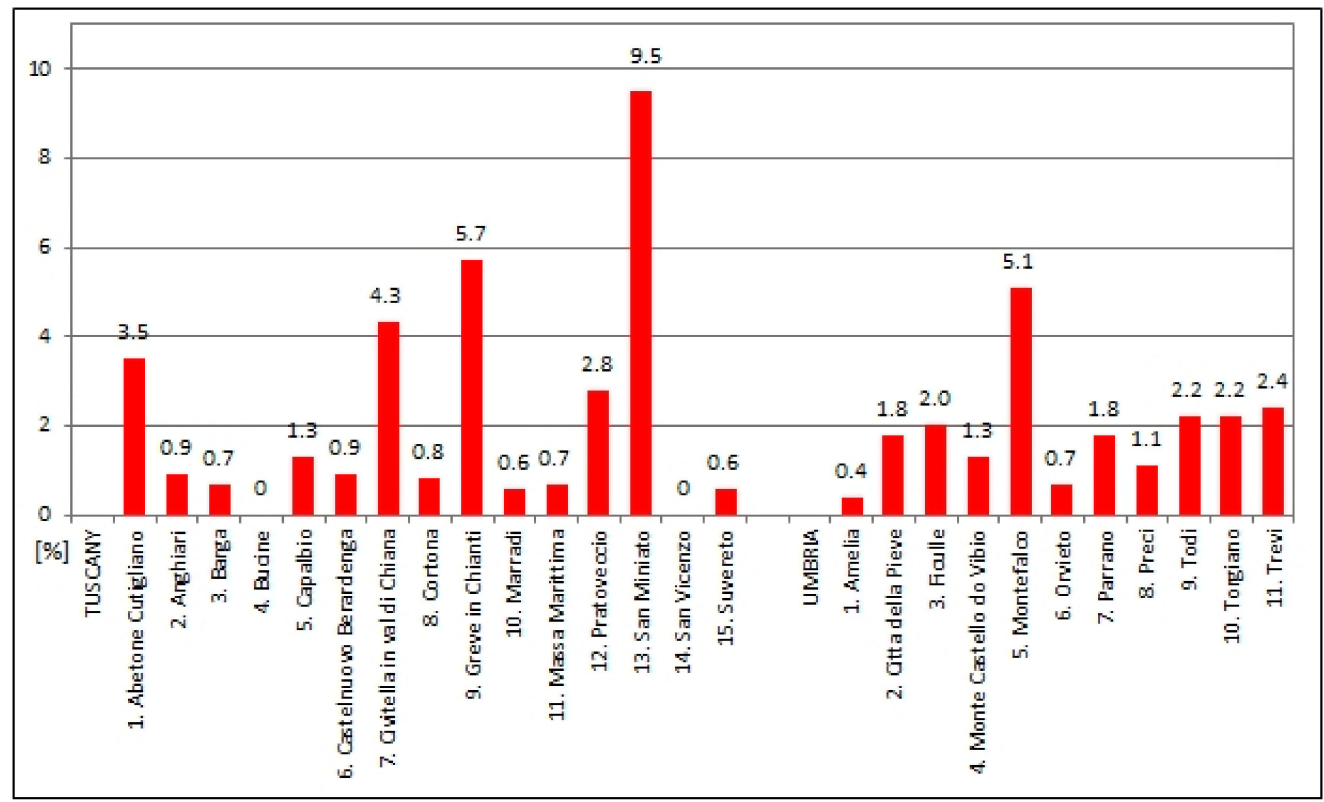

Figure 7. Relative market square area in Italian towns. Source: own elaboration. Key: zero values denote cities without fortified walls.

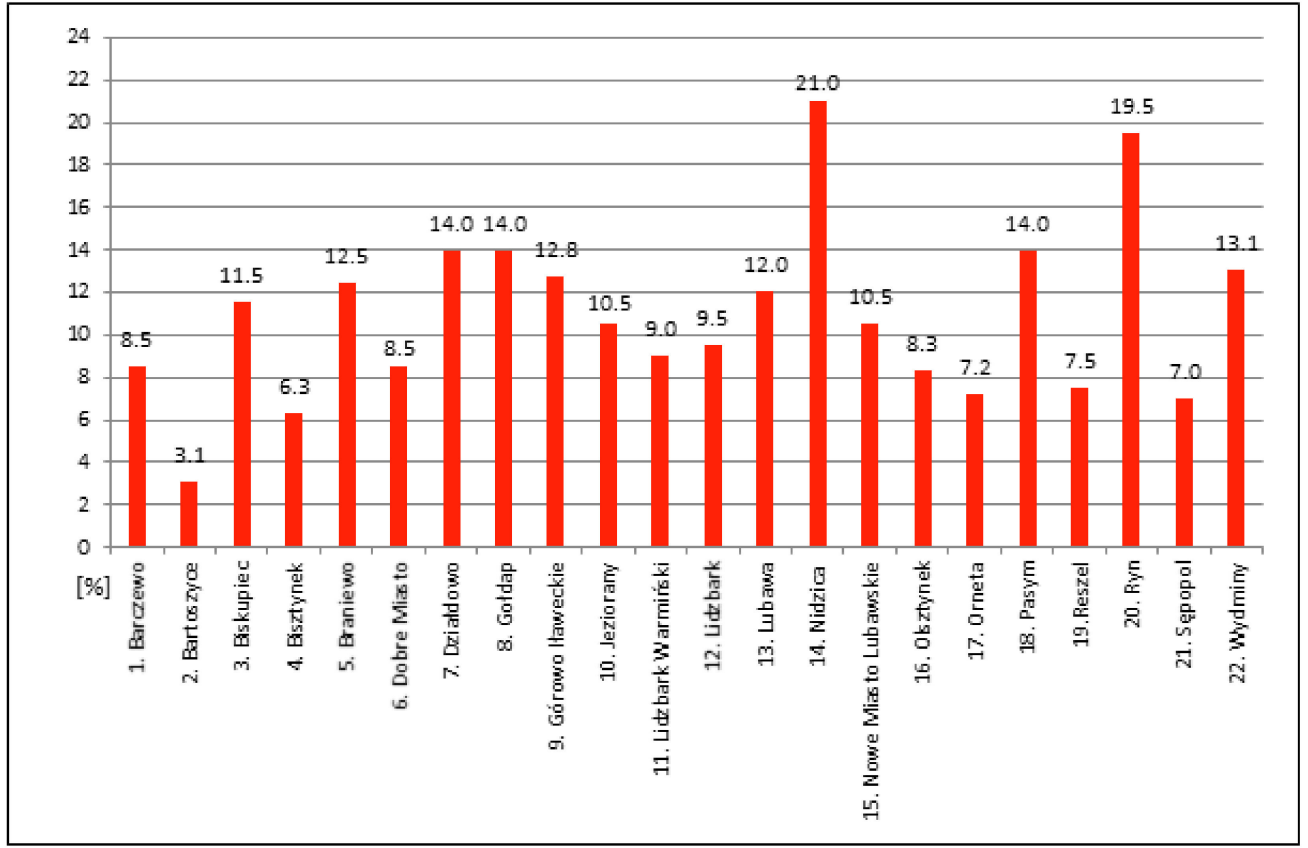

Figure 8. Relative market square area in Polish towns. Source: own elaboration. 


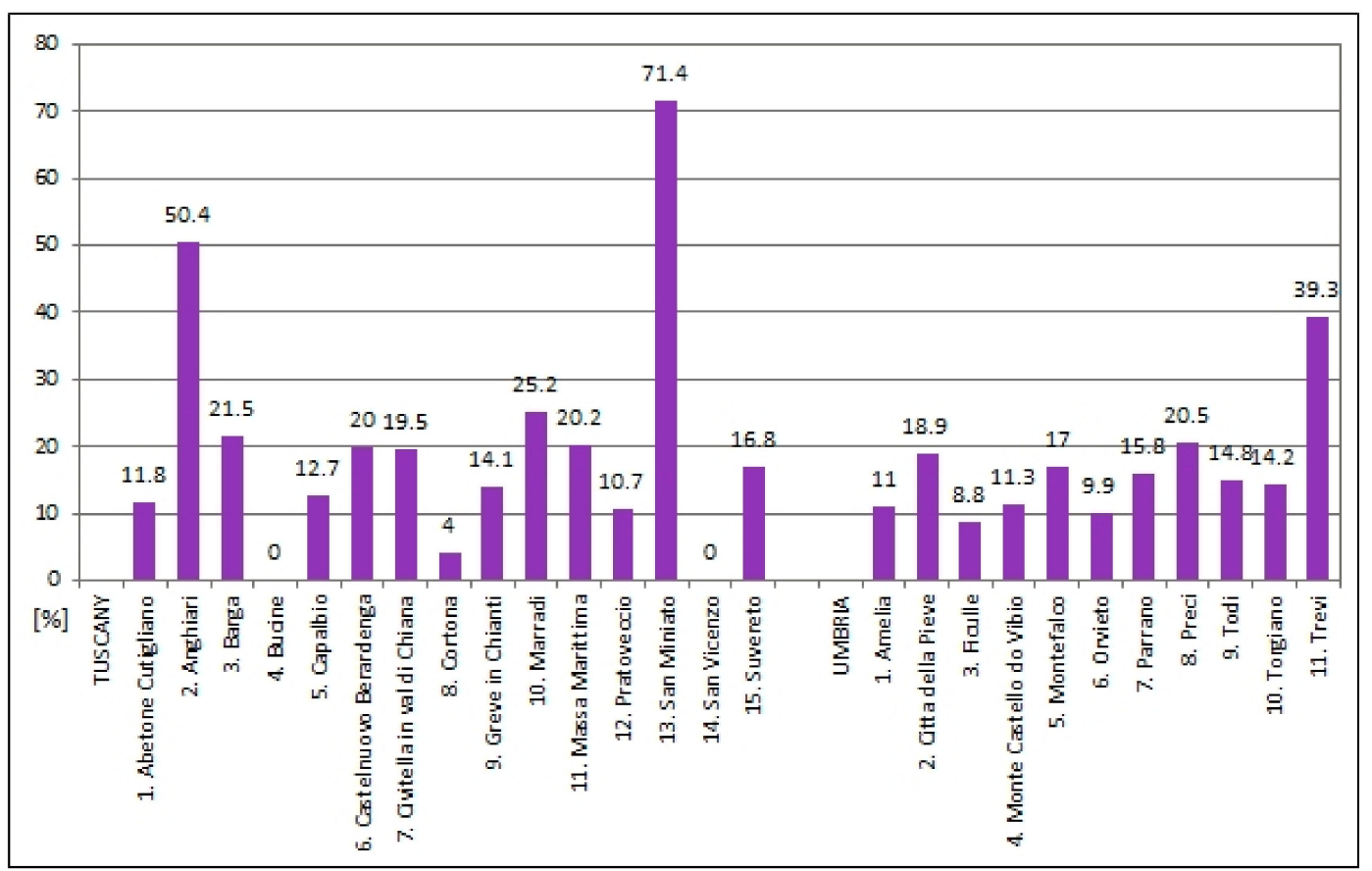

Figure 9. Increase in the developed area of Italian towns. Source: own elaboration. Key: zero values denote towns where the historical urban fabric was not preserved.

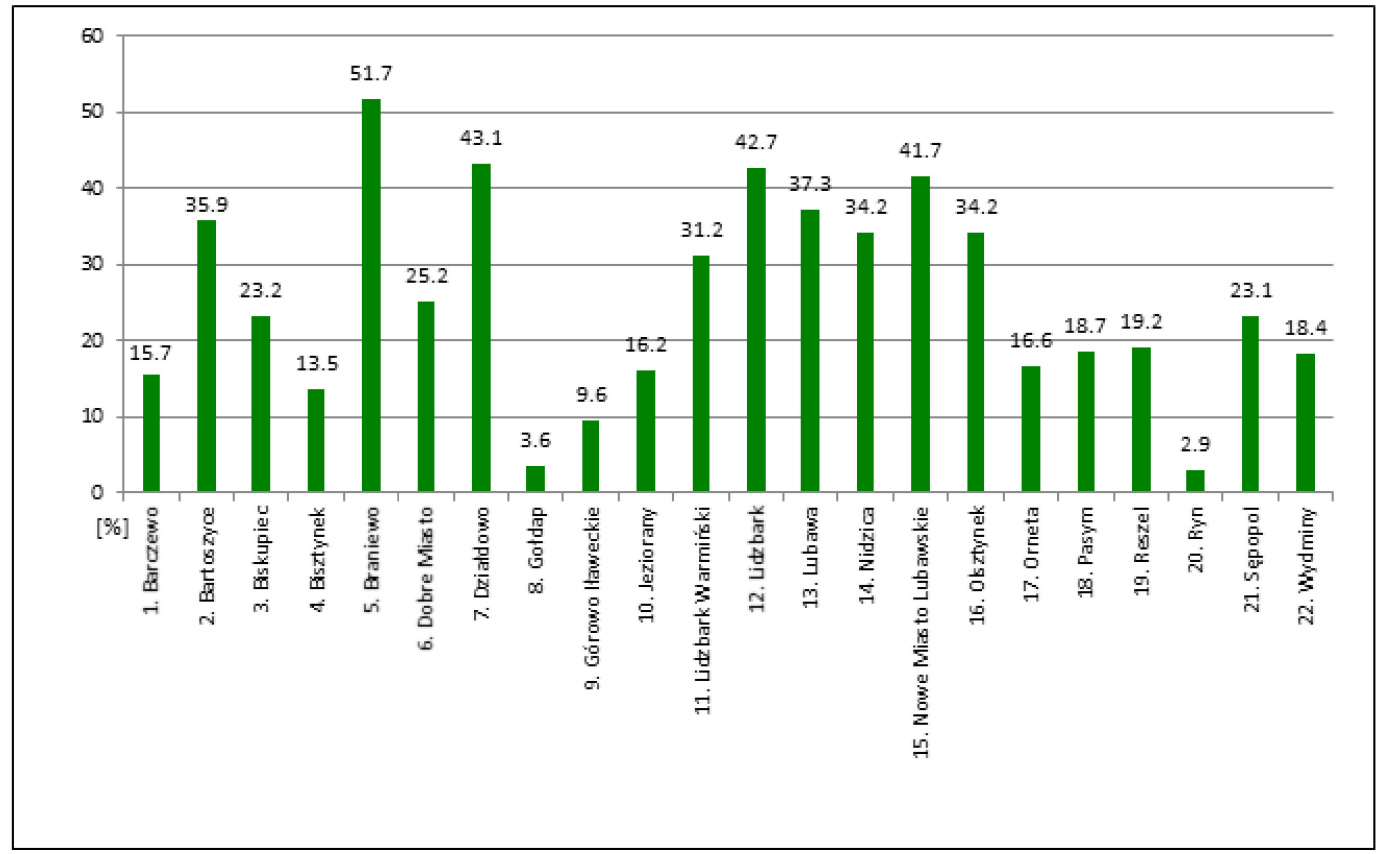

Figure 10. Increase in the developed area of Polish towns. Source: own elaboration.

\subsection{Evaluation of the Influence of Spatial Attributes on the Townscape-Results}

An analysis based on the adopted criteria (Tables 4-8-urban layout, public urban spaces such as municipal squares, pocket parks and municipal parks, architecture, scale of urban development) revealed that historical solutions considerably influenced urban planning in successive centuries. Historical town centers are characterized by different scale, density and type of development than other built-up areas, and they constitute the focal points in the studied towns (Tables 13-15). 
Table 13. Preservation of historical spatial components in Tuscan towns.

\begin{tabular}{|c|c|c|c|c|c|c|c|c|c|c|c|c|c|c|c|}
\hline \multicolumn{16}{|c|}{ TUSCANY } \\
\hline $\begin{array}{c}\text { Criteria for Evaluating the } \\
\text { Preservation of Historical } \\
\text { Spatial Layout }\end{array}$ & 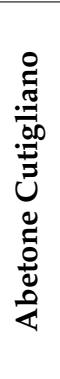 & 疍 & 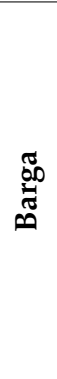 & $\underset{\overbrace{}}{\mathscr{\Xi}}$ & $\begin{array}{l}\frac{0}{0} \\
\frac{0}{\pi} \\
\frac{0}{0}\end{array}$ & 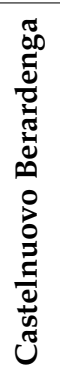 & 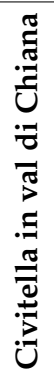 & Õ் & 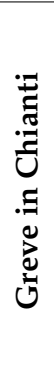 & 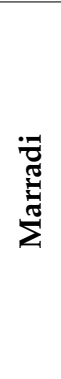 & 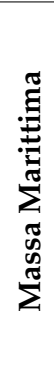 & 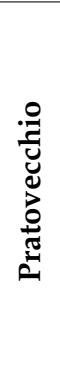 & 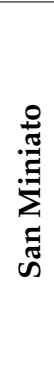 & 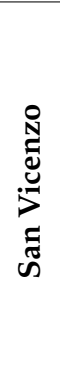 & ڤ⿱艹 \\
\hline \multicolumn{16}{|l|}{ Historical urban layout } \\
\hline \multicolumn{16}{|l|}{ Old market square } \\
\hline \multicolumn{16}{|l|}{ Historical architecture } \\
\hline Dominant buildings & & & & & & & & & & & & & & & \\
\hline
\end{tabular}

Source: own elaboration. Key: $₫$ Preserved $₫$ Not preserved $₫$ Partly preserved.

Table 14. Preservation of historical spatial components in Umbrian towns.

\begin{tabular}{|c|c|c|c|c|c|c|c|c|c|c|c|}
\hline \multicolumn{12}{|c|}{ UMBRIA } \\
\hline $\begin{array}{c}\text { Criteria for Evaluating the } \\
\text { Preservation of Historical } \\
\text { Spatial Layout }\end{array}$ & 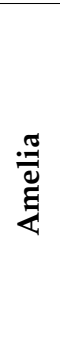 & 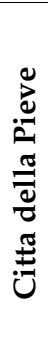 & 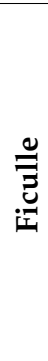 & 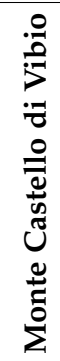 & 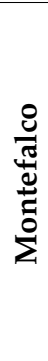 & $\overbrace{0}^{\frac{0}{2}}$ & 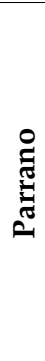 & تِّ & تَّ & 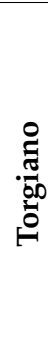 & $\overbrace{}^{3}$ \\
\hline \multicolumn{12}{|l|}{ Historical urban layout } \\
\hline \multicolumn{12}{|l|}{ Old market square } \\
\hline \multicolumn{12}{|l|}{ Historical architecture } \\
\hline Dominant buildings & & & & & & & & & & & \\
\hline
\end{tabular}

Source: own elaboration. Key: $₫$ Preserved $₫$ Not preserved $₫$ Partly preserved.

Table 15. Preservation of historical spatial components in Polish towns in the Region of Warmia and Mazury.

\section{WARMIA AND MAZURY}

Criteria for Evaluating the Preservation of Historical Spatial Layout

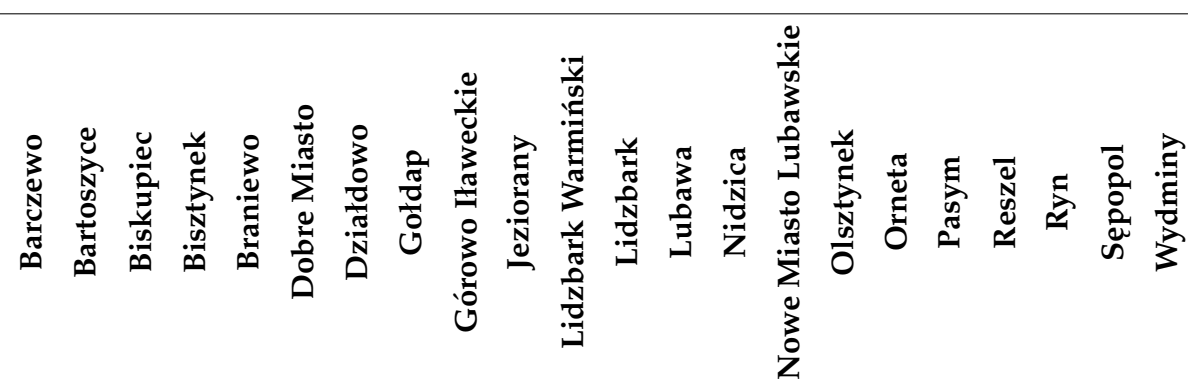

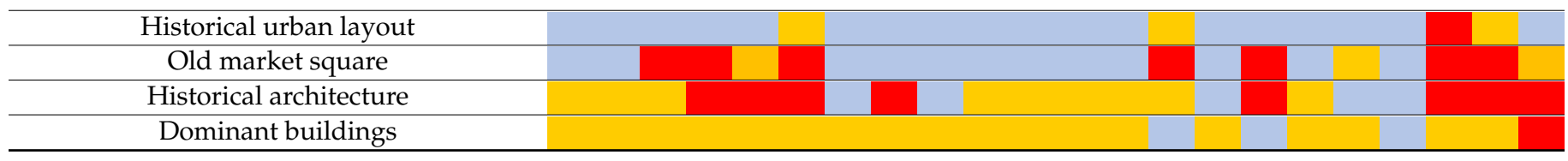




\subsection{Analysis and Evaluation of the Spatial Structure of the Studied Towns-Results}

The distinctive atmosphere (genius loci) of a town is determined by various components of the urban fabric, including material factors as well as non-material factors which cannot be quantified, but which influence the human senses and are responsible for esthetic perceptions of space. The studied towns differed considerably in subjective perceptions of esthetic appeal (Tables 16-18).

Table 16. Genius loci in Tuscan towns.

\begin{tabular}{|c|c|c|c|c|c|c|c|c|c|c|c|c|c|c|c|}
\hline \multicolumn{16}{|c|}{ TUSCANY } \\
\hline $\begin{array}{c}\text { Criteria for Evaluating the } \\
\text { Preservation of Historical } \\
\text { Spatial Layout }\end{array}$ & 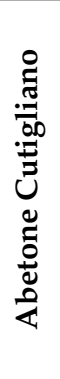 & 胥 & 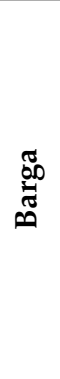 & $\underset{\Xi}{\mathscr{g}}$ & 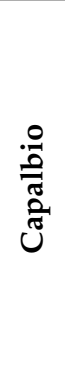 & 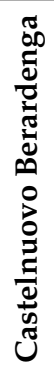 & 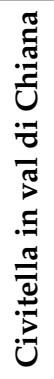 & 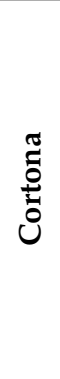 & 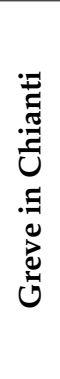 & 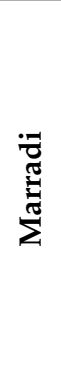 & 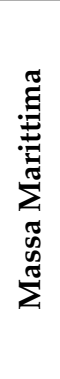 & 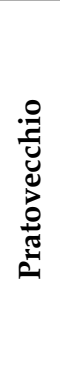 & 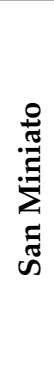 & 㣽 & 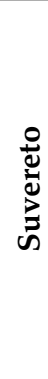 \\
\hline Genius loci of the urban fabric & & & & & & & & & & & & & & & \\
\hline
\end{tabular}

Source: own elaboration. Key: $₫$ Preserved $₫$ Not preserved $₫$ Partly preserved.

Table 17. Genius loci in Umbrian towns.

\begin{tabular}{|c|c|c|c|c|c|c|c|c|c|c|c|}
\hline \multicolumn{12}{|c|}{ UMBRIA } \\
\hline $\begin{array}{c}\text { Criteria for Evaluating the } \\
\text { Preservation of Historical } \\
\text { Spatial Layout }\end{array}$ & $\frac{\pi}{\stackrel{\Xi}{\Xi}}$ & 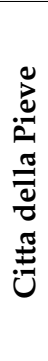 & 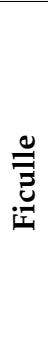 & 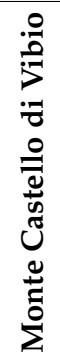 & 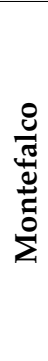 & $\overbrace{0}^{0}$ & 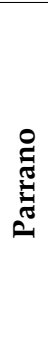 & لَّ & : & 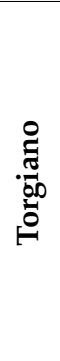 & 胥 \\
\hline $\begin{array}{l}\text { Genius loci of the urban } \\
\text { fabric }\end{array}$ & & & & & & & & & & & \\
\hline
\end{tabular}

Source: own elaboration. Key: $₫$ Preserved $\backsim$ Not preserved $₫$ Partly preserved.

Table 18. Genius loci in Polish towns in the Region of Warmia and Mazury.

Criteria for Evaluating the Preservation of Historical Spatial Layout

\section{WARMIA AND MAZURY}

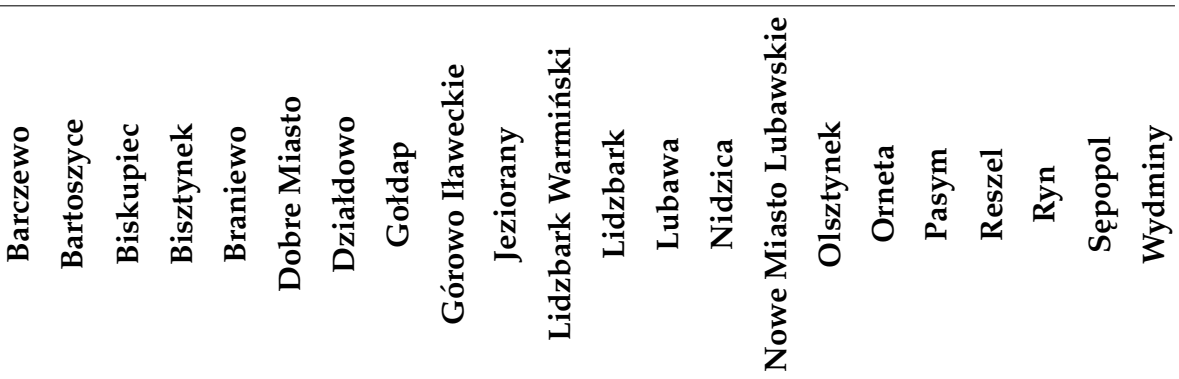

Genius loci of the urban fabric

Source: own elaboration. Key: $\approx$ Preserved $\_$Not preserved $\approx$ Partly preserved. 


\section{Discussion}

Cittaslow towns are conjoined with a rich and long history as well as the charm of places ostensibly frozen in time. While analyzing the localization conditions of the Cittaslow network, it is hard to find any regularity. They represent different geographical, historical and most of all spatial types. They are conjoined mainly by the fact that they have historical centers and/or protected areas. Cultural heritage, valuable landscape, local culture and language are appreciated by Cittaslow towns' authorities, inhabitants and tourists. "Slow" cities lay emphasis on all of the values and owing to that they get unique character $[67,68]$.

Historical planning solutions elicit the strongest emotional responses in perceptions of urban space; they contribute to a sense of local identity and create a sense of responsibility for one's place of residence. The protection and promotion of these values constitute the fundamental tenets of the Cittaslow philosophy $[69,70]$. It should be mentioned that towns that join Cittaslow network commit themselves to keep the cultural heritage connected with the way of living and living conditions [71,72]. Therefore, they achieve the goals of the movement connected with taking care of the historic urban fabric, renovating monuments and towns' aesthetics [73]. It is connected with maintaining and cultivating their historical identity which is not always connected with the functional demands of modern times. Technical and technological development, fire regulations or the civilization progress in general are a challenge in adjusting historical structures to the modern demands. Unlike big cities, small towns have no possibilities for developing industry, building large shopping centers or thoroughfare [74]. The analyzed Polish and Italian towns have many similarities, such as the size of the original urban settlement. However, they differ in other respects, which can be attributed to cultural and climatic differences. Historical urban planning solutions play an important role in this comparison because they testify to the towns' rich cultural heritage which followed European trends in urban design and architecture. The analyzed urban layout is also indicative of differences in local building traditions [75-77]. Qualitative improvement of the built environment should acknowledge local divergence and models as the manifestation of local identity. The greater awareness of key social factors in urban planning and creating architecture influence the higher potential of social sustainability of residential environment [78]. The extent to which urban design components determine the attractiveness of historical towns was evaluated based on the results of field surveys and analyses of iconographic materials. This is a very important consideration in small towns where the physical attributes of space are closely related with the spiritual needs of public space users. It is particularly visible in Slow Cities that apart from rich cultural heritage also have other important endogenous assets: widely underestimated bond and social awareness, and cooperation skills that stem from a deep sense of belonging to the inhabited place $[67,79]$. Consequently, the inhabitants feel like taking responsibility for their town which is definitely easier to be done in small local societies, where unlike in cities, the bonds are usually really strong $[26,74,80]$. The applied research methods supported the identification of links between the quality of historical urban space and the local standards of living. These methods were also successfully used to determine why small historical towns uphold the Cittaslow philosophy and whether different urban layouts in Polish and Italian towns create equal opportunities for implementing the principles of the slow living movement.

The analyzed Italian towns do not differ considerably in urban layout despite the fact that they were founded in different periods of time. The free compositional arrangements are dominant in Italian towns, which could have been connected with transforming former settlements, topography, climate and historical conditioning [81]. The factors, regardless of the widely-acknowledged in the Middle Ages rules of town layout, based on the chessboard layout, made the structure of Umbria and Tuscany to exceed the rules of urban composition created centuries ago [82,83]. Regardless of their founding date, the compared urban structures have many similarities, which suggests that climate and local architectural traditions played a key role in the development of urban forms. The layout of Polish towns 
is completely different than Italian towns' layouts. It corresponds to the general rules for founding a town that were current in the Medieval Times. Polish towns are characterized by more regular layouts which are based on the chessboard layout with a regular market in the middle and a perpendicular grid of streets. [45,48]. Nearly all of the evaluated towns in the Region of Warmia and Mazury have a regular, geometric street pattern with a centrally located market square, a fortified castle and a church.

Towns founded in different historical periods are also characterized by varied urban layouts. A grid street pattern is rarely encountered in Italian towns. In these towns, narrow streets are chaotically distributed, and dense development offers shade and refuge in the hot summer months. In the Middle Ages, dense settlement also increased security because smaller areas were easier to defend against enemies. That feature characterizes towns in the whole Europe [84]. Most of the evaluated towns abound in historical architecture which makes a reference to local building traditions and creates urban forms that are characteristic of the cultural landscape of Tuscany and Umbria. A completely different urban layout was observed in Polish towns. Warmian and Masurian towns were founded on a rectangular street plan, and they were divided into blocks of dense development with a market square in the center [85]. The original urban layout is still legible in most towns. Despite the above, the historical architecture of Polish towns was largely destroyed at the end of World War II. Consequently, the most valuable and the oldest parts of buildings, sometimes the vivid symbols, buildings acknowledged as the elements that shaped the individual landscape of the towns were degraded. Unfortunately, the post-war reconstruction effort, as well as their development, were very often unsuccessful and they often worked the opposite to the historical functional layout, arrangement and the scale of building that had been functioning in historical Polish towns for centuries $[33,86]$. At that time Poland belonged to the Eastern Block which negatively influenced the maintenance of historical identity of the towns. The post-war reconstruction was done without respect for historical assumptions which consequently led to losing towns' historical character [87].

Polish and Italian towns were established in areas with different landform and natural features. Most Italian towns were founded on steep hills that are ubiquitous in Tuscany and Umbria [88-90]. Hills are local topographic features which acted as natural barriers and protected towns and their inhabitants. In contrast, north-eastern Poland abounds in rivers and lakes which were the main focal points during the establishment of Medieval towns. Many Polish towns were nested in the bend of a river. It was done mainly because a river was indispensable for life. It provided water for people and animals, allowed for gathering food, watered crops, and fertilized soils. Close vicinity to rivers had also served military purposes [91]. Security was of the utmost concern in Medieval times, and towns were founded in areas where local terrain features offered effective protection. Moreover, a river facilitated trade and communication enabled professions that required the presence of water; it allowed draining the rain and urban pollution or using energy resources of river flow. Its close vicinity to a large extent influenced the economic development and it also had an impact on political, demographical and social relations of towns located close to the river [91].

The size of Medieval towns was determined by their ability to satisfy the residents' basic needs, and the complex process of building fortified walls favored dense development. Throughout the centuries, defensive walls limited the territorial expansion of cities whose size was fairly similar and representative of the level of technological advancement in the Middle Ages [92]. The average area of towns enclosed by fortified walls was similar in all studied regions, although it was somewhat larger in Italian towns (Cortona, Amelia and Todi). Polish towns were characterized by similar size, with the exception of Gołdap and Ryn.

Traders sold their goods in centrally located market squares which fueled the economic growth of Medieval towns. The market square was the heart of the town, and its location influenced the urban development pattern in the remaining parts of the town. The size and shape of the market square were determined by the town's area and street pattern [92]. The 
vast majority of towns in the Region of Warmia and Mazury have rectangular and square markets. Only three market shapes were identified in this region, which could be attributed to the fact that Polish towns were founded in the same historical period. The shape of market squares in Italian towns is more varied. A trapezoidal shape was most frequently encountered, followed by rectangular markets and markets with a complex shape. A total of seven market shapes were identified in the study, but none of the analyzed Italian towns had square-shaped markets. The observed variations are associated with considerable differences in the founding dates of Italian towns.

The functions of market squares have been expanded in the modern times. Market squares are not only the hubs of commercial and economic activity, but they also serve representative and recreational purposes $[93,94]$. They are historical landmarks that contribute to a sense of local identity and attract tourists and potential investors [95]. The relative area of the market square differs considerably between Italian and Polish towns. The studied towns in the Region of Warmia and Mazury are characterized by significantly higher relative market area which was determined at $10.74 \%$ on average and reached up to $20 \%$ in Nidzica and Ryn. In Italian towns, relative market square area approximated $10 \%$ only in San Miniato (Tuscany). These variations can be attributed to differences in founding dates. Polish towns were established later than their Italian counterparts, and most of them were not built around the existing settlements, but from a "raw root". From the beginning of their existence, Polish towns were adapted to local needs, and the relative proportions of the market square to the remaining forms of urban development could be freely shaped.

Towns are living organisms that continue to evolve, and their territorial reach changes throughout time. The growth and expansion of towns are determined by their regional and supra-regional status, economic performance, quality of space, and standards of living [96-98]. These factors influence the rate of urban expansion in the course of decades and centuries. In Polish towns, built-up area increased most rapidly in the 19th century when small factories (mills, breweries, lumber mills, brick factories) and railway lines were built in the Region of Warmia and Mazury [47]. The expansion of Italian towns was less dynamic due to topographic barriers (closed-form cities established on hills).

Preservation of historical spatial components significantly influences the shaping and perceptions of urban space. The elements, such as urban layouts, i.e., streets, squares, urban interiors and architecture, create the picture of historical changes. The elements to a large extent influence the spatial identity of towns [99]. In the towns of the analyzed areas, the differences are significant. All preservation criteria have been met in Umbrian towns, excluding Torgiano and, partly, Preci. The historical environment of Tuscan towns has also been successfully preserved (excluding Bucine, Civitella in val di Chiana, Pratovecchio, San Vicenzo and, partly, Abetone Cutigliano). The historical urban layout of Polish towns has been partly maintained or lost. Only the first two criteria in Table 15 have been preserved to a satisfactory degree.

The genius loci notion is indispensably connected with the perception of town space. It is not material, the places are special. They are the source of spiritual experience connected with history, the meaning, symbols and aesthetics which are individually perceived. Urban space, individual in every case, is prestigious, "the tokens" of a town with which the inhabitants identify. This relation equals the sense of belonging to a given cultural circle [100]. The significance of the places is unquestionable as it is consolidated in social awareness by particular events, representational buildings or functions [101]. In urban space, it is significant as town planning and architecture enrich the spiritual sphere, they are born in social space which remains as the space full of meanings and symbols, especially in historical towns [102]. For this reason the genius loci is the most subjective and elusive factor in evaluations of historical urban forms. Historical downtown areas differ considerably from the remaining parts of the urban fabric, and they have distinctive features that have been adapted to contemporary needs without a loss of local identity. The results of the study revealed that the preservation of historical spatial components 
is directly responsible for the unique ambience of historical towns. This observation is validated by the fact that Torgiano and Preci are the only Umbrian towns without a genius loci. There are no discernible elements that would signify the rich history of the town. The urban layout and architecture do not have hallmarks of historical solutions as space is organized rather in a modern way. In Tuscany, the pervading spirit of a place is also most strongly manifested in towns whose historical environment has been successfully preserved. Polish Medieval towns have been most severely deprived of their historical ambience, and the genius loci has been retained in only six towns (Działdowo, Górowo Iławeckie, Nowe Miasto Lubawskie, Orneta, Pasym, Reszel). In the remaining cases, the spatial solutions do not have any historical features. After World War II their urban layout was changed and the architecture of socialism vividly stood out from the stylistics that had been created for centuries.

To summarize, one can state that towns that ate members of Cittaslow network develop according to the same set of criteria which is at the same time the benchmark of developmental standards. However, it is so profound that it allows for shaping the local specialization in an individual way. Every town has its own unique endogenous potential which under some conditions can contribute to real development and raising its inhabitants' quality of life $[67,103]$, and the same time achieving the goals of functioning of Cittaslow movement.

\section{Conclusions}

Small historical towns offer a glimpse into Europe's wealthy cultural and architectural heritage. The original spatial structure of these towns has been preserved to a varied extent. Cittaslow International is a network of small towns which prioritizes the quality of life over the hustle and bustle of modern cities. The article analyzes and evaluates historical spatial forms in Cittaslow towns situated in selected European regions with a different culture and history. The relationships between the urban layout and the local quality of life based on sustainable development and protection of cultural heritage were examined.

The study revealed that the Medieval layout of Polish and Italian towns can be successfully incorporated in the modern urban fabric to promote the Cittaslow philosophy of sustainable development and slow living. Cittaslow towns are characterized by small size and population, small-scale urban development and user-friendly public spaces that promote a sense of local identity and foster responsibility for one's place of residence. Historical spatial layouts of the towns (downtown built-up areas) are not adjusted to the modern functional specificity of a big city and its dynamics. There is no possibility for industrial development, building large-areas shopping centers, organizing public transport or building thoroughfare. The small scale of the area in the town center makes social integration an inevitable element of its functioning.

Moreover, historical towns have distinctive spatial features, including small squares, narrow streets that are closed off to vehicular traffic, and historical architecture that triggers emotional responses. These components facilitate the implementation of the Cittaslow concept that advocates harmonious relations between the past, i.e., the preservation and promotion of local traditions and cultural heritage, and the future, i.e., economic growth and an improvement in living standards. Even though Polish and Italian towns have differences in their layouts and character, they still have a common feature-the cozy space organization which being combined with old but well-functioning architecture corresponds to Cittaslow assumptions.

The analyses demonstrate that the components can be applied for spaces developed in a various way, both Polish and Italian towns. Historical urban fabric favors pedestrian movement, which contributes to the formation of stronger social bonds, unlike in large metropolitan areas where social interactions are scarce. Dense development in small towns eliminates physical barriers to human contact, such as extensive open spaces, wide roads and large plots of land zoned for development. These findings indicate that in order to preserve the historical urban fabric, the structure should not be interfered with. Effective 
planning policies are required to preserve the scale, unique character and identity of historical towns, and they facilitate the achievement of Cittaslow goals. Historical spatial layout and urban structures promote local arts, crafts and services. Preservation of local traditions and cultural heritage contributes to the development of tourism, and modern technology (such as remote work arrangements) improves the quality of local life.

Historical urban fabric is an element of cultural heritage and one of the pillars of the tourism industry which creates ample opportunities for promoting the values of towns and regions. Therefore, the results of this study can be used by local authorities to establish cooperation networks, promote their towns and regions, and exchange experiences relating to the implementation of local development policies. The proposed research methods are largely universal and can be applied to analyze the spatial structure of small towns in other regions of the world. The study adds to the existing body of knowledge relating to the development of historical urban forms and spatial layout. The possibility for comparing Polish and Italian towns, which differ in many above-mentioned aspects, proves the point. The methodology is therefore universal and can contribute to the comprehension and further development of the Slow City idea in various regions in the world. Moreover, it can be used as a key element in building local urban revitalization programs for historical towns. Such practice is commonly applied in urban planning in numerous European regions. However, during conducting the research one should be aware of the limitations connected with the lack of a unified database for given countries and the limitations of the access to iconographic and cartographic resources.

Author Contributions: Conceptualization, M.Z., K.P. and A.S.; methodology, M.Z., K.P. and A.S.; formal analysis, M.Z.; investigation, M.Z. and K.P.; resources, M.Z.; data curation, M.Z. and K.P.; writing—original draft preparation, M.Z., K.P. and A.S.; writing—review and editing, K.P. and A.S.; visualization, M.Z.; supervision, A.S.; project administration, M.Z. All authors have read and agreed to the published version of the manuscript.

Funding: This research received no external funding.

Institutional Review Board Statement: Not applicable.

Informed Consent Statement: Not applicable.

Data Availability Statement: Publicly available datasets were analyzed in this study. This data can be found here: http:/ / asict.arte.unipi.it/index.html/ (accessed on 18 August 2020), http:/ / www.cittaslow. org/ (accessed on 30 August 2020), www.istat.it (accessed on 30 August 2020), www.cittaslow.it (accessed on 30 August 2020), www.google.com/maps (accessed on 30 August 2020), https: / cittaslowpolska.pl/ (accessed on 30 August 2020).

Conflicts of Interest: The authors declare no conflict of interest.

\section{References}

1. Broadway, M. Implementing the Slow Life in Southwest Ireland: A Case Study of Clonakilty and Local Food. Geogr. Rev. 2015, 105, 216-234. [CrossRef]

2. Miele, M. CittàSlow: Producing Slowness against the Fast Life. Space Polity 2008, 12, 135-156. [CrossRef]

3. Servon, L.J.; Pink, S. Cittaslow: Going Glocal in Spain. J. Urban. Aff. 2015, 37, 327-340. [CrossRef]

4. Cittaslow International. Available online: http://www.cittaslow.org/ (accessed on 30 August 2020).

5. Mayer, H.; Knox, P.L. Slow Cities: Sustainable Places in a Fast World. J. Urban. Aff. 2006, 28, 321-334. [CrossRef]

6. Orhan, M. Different Approach to Forming Sustainable Cities: Cittaslow. J. Environ. Prot. Ecol. 2017, 18, $1017-1026$.

7. Baldemir, E.; Kaya, F.; Şahin, T.K. A Management Strategy within Sustainable City Context: Cittaslow. Procedia Soc. Behav. Sci. 2013, 99, 75-84. [CrossRef]

8. Mallet, S. The Cittaslow Label and its Spreading in France: The Slow to Produce Sustainable Spaces? Territoire en Mouvement. Revue de Géographie et d'Aménagement 2018. [CrossRef]

9. Hoeschele, W. Measuring Abundance: The Case of Cittaslow's Attempts to Support Better Quality of Life. Int. J. Green Econ. 2010, 4, 63-81. [CrossRef]

10. Perano, M.; Abbate, T.; La Rocca, E.T.; Casali, G.L. Cittaslow \& Fast-Growing SMEs: Evidence from Europe. Land Use Policy 2019, 82, 195-203. [CrossRef] 
11. Zambon, I.; Serra, P.; Bencardino, M.; Carlucci, M.; Salvati, L. Prefiguring a Future City: Urban Growth, Spatial Planning and the Economic Local Context in Catalonia. Eur. Plan. Stud. 2017, 25, 1797-1817. [CrossRef]

12. Feliú, E.G.; Vera, J.R.; Villalón, E.P.; de Castro, J.C.P. Urban Modernization and Heritage in the Historic Centre of Santiago de Chile (1818-1939). Plan. Perspect. 2020, 35, 91-113. [CrossRef]

13. Rossi, D.; Paciotti, D.; Calvano, M. Visionaria. An Open Design Approach for the Regeneration of Historical Urban Heritage. In Proceedings of the Advances in Additive Manufacturing, Modeling Systems and 3D Prototyping, Washington, DC, USA, 24-28 July 2019; Di Nicolantonio, M., Rossi, E., Alexander, T., Eds.; Springer International Publishing: Cham, Switzerland, 2020; Volume 975, pp. 190-201.

14. Abastante, F.; Lami, I.M.; Mecca, B. How to Revitalise a Historic District: A Stakeholders-Oriented Assessment Framework of Adaptive Reuse. In Values and Functions for Future Cities; Mondini, G., Oppio, A., Stanghellini, S., Bottero, M., Abastante, F., Eds.; Green Energy and Technology; Springer International Publishing: Cham, Switzerland, 2020; pp. 3-20, ISBN 978-3-030-23786-8.

15. Atkinson, R. The Small Towns Conundrum: What Do We Do about Them? Reg. Stat. 2019, 9, 1-17. [CrossRef]

16. Senetra, A.; Szarek-Iwaniuk, P. Socio-Economic Development of Small Towns in the Polish Cittaslow Network-A Case Study. Cities 2020, 103, 102758. [CrossRef]

17. Jaszczak, A.; Kristianova, K.; Pochodyła, E.; Kazak, J.K.; Młynarczyk, K. Revitalization of Public Spaces in Cittaslow Towns: Recent Urban Redevelopment in Central Europe. Sustainability 2021, 13, 2564. [CrossRef]

18. Farelnik, E.; Stanowicka, A.; Wierzbicka, W. The Effects of Membership in the Polish National Cittaslow Network. Equilibrium. Q. J. Econ. Econ. Policy 2021, 16, 139-167. [CrossRef]

19. Hatipoglu, B. "Cittaslow": Quality of Life and Visitor Experiences. Tour. Plan. Dev. 2015, 12, 20-36. [CrossRef]

20. Brodziński, Z.; Kurowska, K. Cittaslow Idea as a New Proposition to Stimulate Sustainable Local Development. Sustainability 2021, 13, 5039. [CrossRef]

21. Zadęcka, E. Zrównoważony Rozwój Małych Miast w Świetle Warunków i Wymogów Stowarzyszenia Cittaslow. Zesz. Nauk. Politech. Częstochowskiej Zarządzanie 2017, 25, 35-48. [CrossRef]

22. İlhan, Ö.A.; Karakaş, E.; Özkaraman, B. ‘Cittaslow': An Alternative Model for Local Sustainable Development or Just a Myth? Empirical Evidence in the Case of Tarakli (Turkey). Quaest. Geogr. 2020, 39, 23-37. [CrossRef]

23. Pink, S. Sense and Sustainability: The Case of the Slow City Movement. Local Environ. 2008, 13, 95-106. [CrossRef]

24. Zagroba, M.; Gawryluk, D. Revitalisation as a Method of Planning Sustainable Development of Old Town Complexes in Historic Towns; IOP Publishing: Bristol, UK, 2017; Volume 95, pp. 1-10.

25. Mumford, L. The Culture of Cities; Secker \& Warburg: London, UK, 1944; ISBN 978-0-15-623301-9.

26. Pawłowska, K. Idea Swojskości Miasta; Politechnika Krakowska: Kraków, Poland, 2001; ISBN 978-83-7242-201-9.

27. Alexander, C. A City Is Not Tree. Archit. Forum 1965, 122, 58-66.

28. Burgess, E.W. The Urban Community: Selected Papers from the Proceedings of the American Sociological Society, 1925; University of Chicago Press: Chicago, IL, USA, 1926; ISBN 0-598-60431-6.

29. Geddes, S.P. Cities in Evolution: An Introduction to the Town Planning Movement and to the Study of Civics; Ernest Benn Limited: London, UK, 1968; ISBN 0-510-43121-6.

30. Blazy, R. Zagadnienia przestrzenne a postulaty i idee ruchu miast Cittaslow. In Tendencje w Rozwoju Gospodarczym i Przestrzennym Małych Miast w Polsce; Bartosiewicz, B., Ed.; Wydawnictwo Uniwersytetu Łódzkiego: Łódź, Poland, 2016; pp. 7-28, ISBN 17333180 .

31. Mayer, H.; Knox, P.L. Pace of Life and Quality of Life: The Slow City Charter. In Community Quality-of-Life Indicators: Best Cases III; Sirgy, M.J., Phillips, R., Rahtz, D., Eds.; Springer: Dordrecht, The Netherlands, 2009; pp. 21-40, ISBN 978-90-481-2257-8.

32. Castells, M. The Rise of the Network Society; Wiley-Blackwell: Hoboken, NJ, USA, 2010; ISBN 978-1-4443-1951-4.

33. Dimelli, D. Modern Conservation Principles and Their Application in Mediterranean Historic Centers-The Case of Valletta. Heritage 2019, 2, 787-796. [CrossRef]

34. Województwa Warmińsko-Mazurskiego. Ponadlokalny Program Rewitalizacji Sieci Miast Cittaslow; Województwa WarmińskoMazurskiego: Olsztyn, Poland, 2020.

35. Strzelecka, E. Małe miasta a nowoczesne modele rozwoju miast. In Alternatywne Modele Rozwoju Miast. Sieć Miast Cittaslow; Strzelecka, E., Ed.; Wydawnictwo Politechniki Łódzkiej: Łódź, Poland, 2017; pp. 13-40, ISBN 978-83-7283-826-1.

36. Sobczak, A. Ośrodki Badawcze Zajmujące Się Inteligentnymi Miastami. Available online: http://inteligentnemiasta.pl/osrodkibadawcze-zajmujace-sie-inteligentnymi-miastami/5210/ (accessed on 14 July 2021).

37. Hermant-de Callataÿ, C.; Svanfeld, C. Miasta Przyszłości. Wyzwania, Wizje, Perspektywy; Europejska, K., Generalna, D., Eds.; Polityki Regionalnej: Luxembourg, 2011.

38. Alexandrakis, G.; Manasakis, C.; Kampanis, N.A. Economic and Societal Impacts on Cultural Heritage Sites, Resulting from Natural Effects and Climate Change. Heritage 2019, 2, 279-305. [CrossRef]

39. Jaszczak, A.; Denekas, J. Znaczenie Cech Krajobrazu w Kreowaniu Przestrzeni Kulturowej w Układach Regionalnych. Pr. Kom. Kraj. Kult. PTG 2014, 25, 7-18.

40. Kowalczyk, A. Krajobraz kulturowy. In Uwarunkowania i Plany Rozwoju Turystyki; Młynarczyk, Z., Zajadacz, A., Eds.; Turystyka i Rekreacja-Studia i Prace; Wydawnictwo Naukowe UAM: Poznań, Poland, 2008; Volume II, pp. 121-137.

41. Wolfram, K. (Ed.) Zielone Płuca Polski-Walory Przyrodnicze i Kulturowe; Fundacja Zielone Płuca Polski: Białystok, Poland, 2009; ISBN 978-83-62090-04-4. 
42. Wróbel, T. Zarys Historii Budowy Miast; Ossolineum: Wrocław, Poland, 1971.

43. Kostof, S. The City Shaped: Urban. Patterns and Meanings Through History; Thames And Hudson: London, UK, 1991; ISBN 978-0-8212-1867-9.

44. Matthew, D. Atlas of Medieval Europe, 1st ed.; Checkmark Books: New York, NY, USA, 1983; ISBN 978-0-87196-133-4.

45. Słodczyk, J. Historia Planowania i Budowy Miast; Wydawnictwo Uniwersytetu Opolskiego: Opole, Poland, 2012; ISBN 978-83-7395484-7.

46. Benevolo, L. The History of the City, 1st ed.; The MIT Press: Cambridge, MA, USA, 1980; ISBN 978-0-262-02146-3.

47. Czubiel, L.; Domagała, T. Zabytkowe Ośrodki Miejskie Warmii i Mazur; Pojezierze: Olsztyn, Poland, 1969.

48. Tołwiński, T. Urbanistyka T.1: Budowa Miasta w Przeszłości, 2nd ed.; Wydawnictwo Zakładu Urbanistyki Politechniki Warszawskiej: Warszawa, Poland, 1939.

49. Hall, E.T. Ukryty Wymiar; Państwowy Instytut Wydawniczy: Warszawa, Poland, 1978.

50. Rossi, A. The Architecture of the City; MIT Press: Cambridge, MA, USA, 1984; ISBN 978-0-262-68043-1.

51. Wejchert, K. Elementy Kompozycji Urbanistycznej; Arkady: Warszawa, Poland, 1984; ISBN 83-213-3151-3.

52. Norberg-Schulz, C. Genius Loci: Paesaggio Ambiente Architettura; Edizioni Electa: Milan, Italy, 1986; ISBN 978-88-435-1961-3.

53. Montgomery, C. Happy City: Transforming Our Lives through Urban Design; Farrar Straus Giroux: New York, NY, USA, 2013; ISBN 978-1-84614-320-5.

54. Gzell, S. O Architekturze. Szkice Pisane i Rysowane; Blue Bird: Warszawa, Poland, 2014; ISBN 978-83-64870-02-6.

55. Radwan, A. Color in Architecture Is It Just an Aesthetic Value or a True Human Need? Int. J. Eng. Res. Technol. (IJERT) 2015, 4 , 523-533. [CrossRef]

56. Brogiolo, G.P. Le Origini Della Città Medievale; SAP: Walldorf, Germany, 2011; ISBN 978-88-87115-68-0.

57. Ward-Perkins, B. The towns of northern Italy: Rebirth or renewal? In The Rebirth of Towns in the West AD 700-1050; Hodges, R., Hobley, B., Eds.; Council for British Archaeology: London, UK, 1988; pp. 16-27.

58. Boetticher, A. Die Bau-Und Kunstdenkmäler Der Provinz Ostpreußen. Bd. 4: Die Bau- Und Kunstdenkmäler in Ermland; Die Bau- und Kunstdenkmäler der Provinz Ostpreußen; Kommissionsverlag von Bërnh. Teichert: Königsberg, Preußen, 1894 ; Volume 4.

59. Bonk, H. Die Städte und Burgen in Altpreussen (Ordensgründungen) in Ihrer Beziehung zur Bodengestaltung; Ferd. Beyer's Buchhandlung (Thomas \& Oppermann): Königsberg, Preußen, 1895.

60. Maciejczak-Kwiatkowska, Z.; Retko-Bernatowicz, M.; Wiśniewski, R. W Dialogu z Otoczeniem? Społeczne Postrzeganie Przestrzeni Publicznej i Architektury w Polsce; Narodowe Centrum Kultury: Warszawa, Poland, 2018; p. 71.

61. Italian National Institute of Statistics. Available online: www.istat.it (accessed on 30 August 2020).

62. Atlante Storico Iconografico Delle Città Toscane. Available online: http://asict.arte.unipi.it/index.html/ (accessed on 18 August 2020).

63. Ross, I.C. Umbria: A Cultural History (Cultural Guide); Signal Books Ltd.: Oxford, UK, 2013; ISBN 978-1-908493-85-9.

64. Cittaslow Italia. Available online: www.cittaslow.it (accessed on 30 August 2020).

65. Google Maps. Available online: www.google.com/maps (accessed on 30 August 2020).

66. Cittaslow Polska. Available online: https:// cittaslowpolska.pl/ (accessed on 30 August 2020).

67. Mazur-Belzyt, K. Współczesne podstawy rozwoju małych miast na przykładzie sieci miast Cittaslow. Probl. Rozw. Miast 2014, XI, 39-45.

68. Mehanna, W.A.E.-H. Urban Renewal for Traditional Commercial Streets at the Historical Centers of Cities. Alex. Eng. J. 2019, 58, 1127-1143. [CrossRef]

69. Knox, P.L. Creating Ordinary Places: Slow Cities in a Fast World. J. Urban Des. 2005, 10, 1-11. [CrossRef]

70. Presenza, A.; Abbate, T.; Micera, R. The Cittaslow Movement: Opportunities and Challenges for the Governance of Tourism Destinations. Tour. Plan. Dev. 2015, 12, 479-488. [CrossRef]

71. Karatosun, M.; Çakar, D. Effects of Cittaslow Movement on Conservation of Cultural Heritage: Case of Seferihisar \& Halfeti, Turkey. Civ. Eng. Archit. 2017, 5, 71-82. [CrossRef]

72. Jaszczak, A.; Kristianova, K. Social and Cultural Role of Greenery in Development of Cittaslow Towns. IOP Conf. Ser. Mater. Sci. Eng. 2019. [CrossRef]

73. Farelnik, E.; Stanowicka, A.; Wierzbicka, W. Cittaslow-Model Rozwoju i Wspótpracy Małych Miast; UWM w Olsztynie: Olsztyn, Poland, 2020.

74. Pulawska, S.; Starowicz, W. Ecological Urban Logistics in the Historical Centers of Cities. Procedia Soc. Behav. Sci. 2014, 151, 282-294. [CrossRef]

75. Krassowski, W. Dzieje Budownictwa i Architektury na Ziemiach Polskich; Arkady: Warszawa, Poland, $1990 ;$ Volume 2.

76. Pevsner, N. An Outline of European Architecture; Thames \& Hudson: London, UK, 2009; ISBN 0-500-34241-5.

77. Della Spina, L. Multidimensional Assessment for "Culture-Led" and "Community-Driven" Urban Regeneration as Driver for Trigger Economic Vitality in Urban Historic Centers. Sustainability 2019, 11, 7237. [CrossRef]

78. Hargreaves, A. Building Communities of Place: Habitual Movement around Significant Places. J. Hous. Built Environ. 2004, 19, 49-65. [CrossRef]

79. Park, E.; Kim, S. The Potential of Cittaslow for Sustainable Tourism Development: Enhancing Local Community's Empowerment. Tour. Plan. Dev. 2015, 351-369. [CrossRef] 
80. Sztabiński, P.B.R.; Sztabiński, F. Przywiązanie do miejsca zamieszkania jako wymiar polskiego tradycjonalizmu. In Elementy Nowego Ładu; Domański, H., Rychard, A., Eds.; Wydaw. IFiS PAN: Warszawa, Poland, 1997; pp. 256-269, ISBN 978-83-86166-87-9.

81. Piccinato, L. Urbanistica Medievale; Dedalo: Bari, Italy, 1993; ISBN 978-88-220-3306-2.

82. Valenti, M. Architecture and Infrastructure in the Early Medieval Village: The Case of Tuscany. Technol. Transit. A.D. 300-650 2006, 451-489. [CrossRef]

83. Randelli, F.; Romei, P.; Tortora, M.; Mossello, M. Rural Tourism Driving Regional Development in Tuscany. The Renaissance of the Countryside. Dip. Di Sci. Econ. Univ. Degli Studi Di Firenze Work. Pap. Ser. 2012, 11, 1-21.

84. Bogdanowski, J. Architektura Obronna w Krajobrazie Polski. Od Biskupina do Westerplatte; Wydawnictwo Naukowe PWN: Warszawa, Poland, 2002; ISBN 83-01-12223-4.

85. Paszkowski, Z. Historia Idei Miasta: Od Antyku Do Renesansu; Wydawnictwo hogben: Szczecin, Poland, 2015; ISBN 83-63868-51-5.

86. Salm, J. Idea Cittaslow a tożsamość miast województwa warmińsko-mazurskiego. Między Umbria a Warmią i Mazurami. In Alternatywne Modele Rozwoju Miast. Sieć Miast Cittaslow; Strzelecka, E., Ed.; Wydawnictwo Politechniki Łódzkiej: Łódź, Poland, 2017; pp. 74-81, ISBN 978-83-7283-826-1.

87. Basista, A. Betonowe Dziedzictwo: Architektura w Polsce Czasów Komunizmu; Wydawn. Nauk. PWN: Warszawa, Poland, 2001; ISBN 978-83-01-13224-8.

88. Cencetti, C.; Conversini, P.; Tacconi, P. The Rock of Orvieto (Umbria, Central Italy). Giornale di Geologia Applicata 2005, 1, $103-112$. [CrossRef]

89. Falco, E. Transferable Development Rights in Regeneration Schemes for Historic City Centres. Legislation in the Umbria Region. Ital. J. Plan. Pract. 2012, 2, 4-14.

90. Paba, G.; Perrone, C.; Lucchesi, F.; Zetti, I. Territory matters: A regional portrait of Florence and Tuscany. In Post-Metropolitan Territories; Balducci, A., Fedeli, V., Curci, F., Eds.; Routledge: London, UK; New York, NY, USA, 2017; pp. 95-116, ISBN 978-1-31562530-0.

91. Pancewicz, A. Rola Rzek w Rozwoju Przestrzennym Historycznych Miast Nadrzecznych. Woda W Przestrz. Przyodniczej I Kult. 2003, 11, 275-286.

92. Kostrzewska, M. Miasto Europejskie na Przestrzeni Dziejów: Wybrane Przykłady; Akapit-DTP: Gdańsk, Poland, 2013; ISBN 978-8364333-02-6.

93. Czerner, R. Zabudowy Rynków: Średniowieczne Bloki Śródrynkowe Wybranych Dużych Miast Ślaska; Oficyna Wydawnicza Politechniki Wrocławskiej: Wrocław, Poland, 2002; ISBN 978-83-7085-671-7.

94. Przesmycka, E. “Serce” współczesnego miasta. Czas. Techniczne. Archit. 2008, 105, 77-87.

95. Sarzyński, P. Polacy wobec krajobrazu miejskiego. Co nas porusza? In Krajobraz Kulturowo-Przyrodniczy z Perspektywy Społecznej; Ratajski, S., Ziółkowski, M., Eds.; Polski Komitet do spraw UNESCO Narodowe Centrum Kultury: Warszawa, Poland, 2015; pp. 213-228, ISBN 978-83-902939-9-8.

96. Bisaga, A. Małe i średnie miasta jako lokalne centra rozwoju regionalnego. In Rozwój Miast i Zarzadzanie Gospodarka Miejska; Słodczyk, J., Ed.; Wydawnictwo Uniwersytetu Opolskiego: Opole, Poland, 2004; pp. 225-234, ISBN 83-7395-069-9.

97. Orchowska, A. Man, as a User and Observer of the Urban Space. Środowisko Mieszk. 2014, 13, $180-185$.

98. Besson, R. Living cities in two cycles and three movements. In Living Cities. Contributions to the Theme Europan E16 Europan France; Europan France: Montreuil, France, 2019; pp. 15-20.

99. Ostrowski, W. Wprowadzenie do Historii Budowy Miast. Ludzie i Środowisko, 2nd ed.; Oficyna Wydawnicza Politechniki Warszawskiej: Warszawa, Poland, 2001; ISBN 83-86569-28-X.

100. Durrell, L. Spirit of Place. Letters and Essays on Travel; Faber \& Faber: London, UK, 1969; ISBN 0-571-08994-1.

101. Canter, D.V. The Psychology of Place, 1st ed.; Palgrave Macmillan: New York, NY, USA, 1977; ISBN 978-0-312-65322-4.

102. Szymski, A.M. Genius loci-Czyli o odkrywaniu i na nowo definiowaniu znaczeń w istniejacej przestrzeni miejskiej (trzy przykłady). Czas. Techniczne. Archit. 2008, 105, 162-166.

103. Oppido, S.; Ragozino, S.; Esposito De Vita, G. Exploring Territorial Imbalances: A Systematic Literature Review of Meanings and Terms. In New Metropolitan Perspectives; Springer: Berlin/Heidelberg, Germany, 2020; pp. 90-100. 